\title{
VOICES FROM THE OTHER SIDE: PERCEPTIONS OF CAREGIVERS ON OPERATING UNREGULATED HOME-BASED CHILDCARE
}

\author{
by \\ Victoria Popov \\ Bachelor of Arts, Ryerson University, Toronto, 2012 \\ Diploma in Early Childhood Education, Humber Institute of Technology and Advanced \\ Learning, 2005, Toronto \\ A Major Research Paper \\ Presented to Ryerson University \\ in partial fulfillment of the requirements for the degree of \\ Master of Arts \\ in the Program of \\ Early Childhood Studies \\ Toronto, Ontario, Canada 2014
}

C) Victoria Popov 2014 


\section{Author's Declaration}

I hereby declare that I am the sole author of this MRP. This is a true copy of the MRP, including any required final revisions.

I authorize Ryerson University to lend this MRP to other institutions or individuals for the purpose of scholarly research

I further authorize Ryerson University to reproduce this MRP by photocopying or by other means, in total or in part, at the request of other institutions or individuals for the purpose of scholarly research. I understand that my MRP may be made electronically available to the public. 


\title{
VOICES FROM THE OTHER SIDE: PERCEPTIONS OF CAREGIVERS ON OPERATING UNREGULATED HOME-BASED CHILDCARE
}

(C) Victoria Popov 2014

\author{
Master of Arts
}

in the Program of

Early Childhood Studies

\begin{abstract}
The purpose of this qualitative study was to gain a snapshot of the unregulated home-based care sector (UHBC). All seven participants in this study were Caucasian females providing unregulated childcare on a full-time basis within their homes. Data collection took place in the form of semi-structured interviews. The UHBC providers' perceptions about their work were examined through the theoretical lens of the political economy of care that encompasses features such as social reproduction, grey market economy, transnationalization of care, and solutions that address political economy of care. The analysis revealed that the unregulated services UHBC providers offer embody a political economy of care. However, in addressing a political economy of care, the UHBC providers believe that they are meeting families' needs, and wish for a better regulation of UHBC. A possible system of UHBC regulation is proposed.
\end{abstract}

\section{Key Words:}

Unregulated home-based childcare, unlicensed home-based childcare, informal care, political economy of care theory 


\section{Acknowledgements}

I am forever grateful to my participants, providers of unregulated home-based childcare. They took a leap of faith in exposing themselves and their businesses to a stranger. Without them, this project would not be possible. I recognize their devotion to children and families, and the effort they put into the work of caring for children.

I would like to express my gratitude to my supervisor Dr. Rachel Langford. She has provided her ongoing support and encouragement during the turbulent process of conducting research. Her expertise in the issues of care work has been an immense help in increasing my understanding of the care economy. I would like to thank my second reader for this study, Dr. Rachel Berman, for taking on this role. I would like to thank Dr. Angela Valeo, current Chair of the Graduate Program in Early Childhood Studies for taking the time to review this study. I would like to thank Dr. Mehrunissa Ali, former Chair of the Graduate Program in Early Childhood Studies for supporting me as a graduate student.

Finally, I would like to thank my family_my husband, Alexei, and our two children Maya and Zoya, for being my backbone through the tumultuous time of graduate studies. To your patience I am forever indebted. 
Author's Declaration $\quad$ ii

$\begin{array}{ll}\text { Abstract } & \text { iii }\end{array}$

Acknowledgements $\quad$ iv

List of Tables $\quad$ vii

List of Appendices $\quad$ viii

$\begin{array}{ll}\text { Chapter One: Introduction } & 1\end{array}$

$\begin{array}{ll}\text { Home-Based Childcare in Ontario } & 3\end{array}$

$\begin{array}{ll}\text { Chapter Two: Theoretical Framework } & 6\end{array}$

$\begin{array}{lr}\text { Social reproduction of care work } & 8\end{array}$

$\begin{array}{ll}\text { Care work within grey markets } & 9\end{array}$

$\begin{array}{ll}\text { Transnationalization of care } & 11\end{array}$

Solutions to address political economy of care $\quad 11$

$\begin{array}{ll}\text { Chapter Three: Literature Review } & 14\end{array}$

$\begin{array}{ll}\text { Home-based childcare provider } & 14\end{array}$

$\begin{array}{ll}\text { Quality in home-based childcare } & 17\end{array}$

Benefits of home-based childcare $\quad 20$

$\begin{array}{ll}\text { Chapter Four: Methods } & 24\end{array}$

$\begin{array}{ll}\text { Sample and Recruitment } & 25\end{array}$

$\begin{array}{ll}\text { Recruitment challenges } & 27\end{array}$

$\begin{array}{ll}\text { Setting } & \mathbf{3 0}\end{array}$

$\begin{array}{ll}\text { Ethical Considerations } & 30\end{array}$

$\begin{array}{ll}\text { Data Collection } & 31\end{array}$

Data Analysis $\quad 32$ 
$\begin{array}{ll}\text { Chapter Five: Findings } & 34\end{array}$

Getting in the business $\quad 35$

$\begin{array}{ll}\text { Being called unlicensed } & 38\end{array}$

Choosing to remain unregulated $\quad 40$

Responding to the Bill $10 \quad 46$

Being part of early childhood education and care sector 49

$\begin{array}{ll}\text { Chapter Six: Discussion } & 53\end{array}$

Unregulated home-based childcare and social reproduction $\quad 55$

Unregulated home-based childcare: A grey market 59

UHBC providers addressing Political Economy of Care $\quad 63$

$\begin{array}{ll}\text { Home-based childcare within ECEC system } & 65\end{array}$

$\begin{array}{lr}\text { Conclusion } & 67\end{array}$

$\begin{array}{ll}\text { References } & 73\end{array}$ 


\section{List of Tables}

Table 1. Characteristics of UHBC participants 


\section{List of Appendices}

Appendix A. Interview Protocol 


\section{Chapter One: Introduction}

In 2012, in Ontario the number of children from 0-12 years old reached almost two million, and out of these two million, 850 thousand were under the age of five (Friendly, Halfon, Beach \& Forer, 2013). Only 20.8 per cent of these children had access to regulated childcare (Ferns \& Friendly, 2014). Outside of parental care, other children were placed in informal care arrangements that could have encompassed relatives, neighbors, and unregulated home-based childcares (UHBC). However, the majority of informal care was provided by UHBC; although, the exact number of children cared for in UHBC is unknown.

In the past year, the UHBC sector has been immensely scrutinized by the public and childcare activists due to unfortunate tragedies that happened inside four UHBCs. In the span of seven months, four children have died in the care of UHBC providers (Ballingall \& Chown Oved, TorontoStar, 2014). These events resonated with me as a parent who used the services of an UHBC. An UHBC appealed to my needs to have a childcare program delivered in my home language, as well as to my economic means as a student. The UHBC providers that I used were able to meet these needs. My daughter was cared for in a Russian-speaking environment where interactions, activities, and meals embraced Russian culture. Moreover, the cost of childcare services in UHBC were significantly lower than in a centre-based childcare- $\$ 800 /$ month in comparison to an average of $\$ 925 /$ month (Ferns \& Friendly, 2014) in Ontario (a cost of regulated childcare can run much higher in a large urban setting). In addition, an UHBC space was readily available, whereas centre-based childcares have long waiting lists - I recall being told the waitlist was three years long after inquiring about a space in a centre-based childcare for my then one year-old daughter. The ability of UHBC to meet parents' needs like the ones that I had, make UHBC a reasonable choice for families. 
However, the tragedies occurring in UHBC pointed to significant problems with unregulated childcare sector. For instance, Laurie Monsebraaten, a social justice journalist for The Toronto Star, has covered the unregulated childcare sector extensively. In addition to reporting on new developments, her articles reiterate the lack of oversight of UHBCs, positioning licensed care as a better choice. Similarly, the tragic events prompted The Globe and Mail to do a childcare series exposing the struggles parents face trying to find quality care for their children. The author of the series, Erin Anderssen, called the unregulated childcare sector a "grey market" predominantly due to the lack of systematic information about UHBC and its providers. As a consequence of following the media, one can conclude that UHBC is an unfavourable space for young children. Yet, so many parents, including myself, use UHBCs and are satisfied with UHBCs.

Nonetheless, the uproar created by the media, childcare activists and some parents provided an impetus for the Government of Ontario to re-examine the current legislation and practices in respect to UHBC sector. Thus, the Minister of Education, Liz Sandals, introduced Bill 143: Child Care Modernization Act in December 2013. Following the election in June 2014, the Bill was re-introduced as Bill 10 on July $10^{\text {th }}, 2014$, and is currently being reviewed in the legislature. If passed, Bill 10 will replace "Day Nurseries Act", under which childcare sector is currently regulated, with the "Child Care and Early Years Act, 2013 - a new, modernized legislative framework that would govern the provision of child care and early years programs and services" (Ontario. Regulatory Registry, 2014). The new legislation will affect UHBC providers in the following ways. Firstly, UHBC providers will be allowed to care for a maximum of five children under the age of 13, including their own that are under the age of six. Currently, they are allowed to care for five children in addition to their biological children. Secondly, a 
limit on children's ages will be enacted, where out of the five children cared for by the UHBC provider, only two children can be under the age of two. Finally, the fines for infractions will increase from a maximum of $\$ 2,000$ to a maximum of $\$ 100,000$ ("Bill 10", 2014).

All of these events created an impetus for me to research unregulated home-based childcare, particularly the incongruence between my own experience with UHBC and its portrayal in the media. Recognizably, the absence of UHBC providers' voices in the media paints an incomplete picture of the UHBC sector. Thus, the purpose of this study is to provide a snapshot of unregulated home-based childcare sector in Ontario by examining unregulated home-based childcare providers' perceptions of caring for young children. The research question guiding this study is What are operators' perceptions of providing unregulated home-based childcare?

\section{Home-Based Childcare in Ontario}

To better understand home-based childcare, it is important to delineate its different types. In Ontario, home-based childcares fall into three categories: licensed, unregulated and illegal. ${ }^{1}$ Home- based childcares that are considered licensed are contracted through private-home child care agencies (Ontario. Ministry of Education, 2013a). These agencies are licensed by the Ministry of Education to oversee 'licensed' home-based childcares. The Ontario's Ministry of Education lists 125 private-home child care agencies, some of them are for a profit and some are non-for profit organizations (Ontario. Ministry of Education, 2013b). To be licensed by the Ministry, private-home child care agencies undergo a process similar to childcare centre licensing, where they have to meet a set of criteria such as the presence of appropriate behaviour

\footnotetext{
${ }^{1}$ Unregulated home-based childcare is also referred to as unlicensed in the media, and sometimes in government documents. Throughout this report, only the term unregulated will be used.
} 
management policies and a program statement. They are inspected annually by the Ministry personnel. By licensing the agency, the Ministry of Education abdicates the responsibility of ensuring that regulated home-based childcares (RHBC) are in compliance with the "Day Nurseries Act" (1990).

RHBCs are not directly licensed by the Ministry of Education, but are contracted by the private-home child care agencies to provide childcare (Ontario. Ministry of Education, 2013 a). Thus, individuals in RHBC are employees of the private-home child care agencies. As employees of agencies, RHBC providers receive remuneration through agencies. Providers' remuneration encompasses a portion of parents' fees that agencies charge families. The percentage of parents' fees the providers receive varies across agencies.

RHBCs are overseen by the private-home day care agencies' staff-home visitors. Home visitors check the RHBC provider's homes regularly; the frequency of visits depends on privatehome agency's mandate and RHBC provider's rate of compliance. Typically, home visitors check that RHBC providers are following provincial requirements and agency's policies and procedures (Ontario. Ministry of Education, 2013 a). For example, home visitors ensure that RHBC providers comply with "Day Nurseries Act" pertaining to the number of children they can care for, which is a maximum of five children including provider's own children under the age of 13, and no more than two children under the age of two. Furthermore, home visitors connect providers with families who wish to purchase RHBC services, and thus fill vacant childcare spaces. They equip RHBC providers who are just starting out with materials necessary to run a program, and provide them with information about Ontario childcare regulations and early childhood education and care program. In addition, depending on the private-home child care 
agency, agencies provide opportunities to receive various resources such as toys, books and furniture for the program, as well as professional development opportunities.

Unregulated home-based childcares (UHBC) are not affiliated with private home child care agencies. They are not overseen by home visitors, or Ministry personnel, although, they still have to follow "Day Nurseries Act" in regard to the number of children they can care for. UHBC providers can care for the maximum of five children not including their own. For example, an if UHBC provider has three of her own children, she can provide care to any five children in addition to her own, resulting in eight children in her care. In contrast to RHBC providers, UHBC providers are typically self-employed, receiving payment directly from parents. They carry the responsibility of advertising their services, finding resources for their program, creating any policies pertaining to their home childcare and communicating them to parents.

Although neither the Ministry of Education nor the private-home child care agency oversees UHBCs, the Ministry is responsible for responding to public allegations of an UHBC provider caring for more than five children. In this case, Ministry personnel have to visit the UHBC and ensure compliance with the regulation pertaining to numbers. For that matter, UHBC that infringes upon the regulation pertaining to the number of children one allowed to care for is considered an illegal home-based childcare. The Ministry has a right to close down a UHBC that operates illegally if the provider does not comply within reasonable time, and fine the provider \$2000 (Ontario. Ministry of Education, 2014) ${ }^{2}$.

\footnotetext{
${ }^{2}$ Bill 10, Child Care Modernization Act currently being reviewed in the Ontario Legislature, if passed, will increase these fees from $\$ 2000$ per infraction to a maximum of $\$ 100,000$.
} 


\section{Chapter Two: Theoretical Framework}

This study is guided by a theoretical perspective anchored in political economy of care (PEC) theory. Although unregulated home-based childcare (UHBC) can be viewed through a number of lenses, such as ecological lens (Freeman, 2011), a child development lens (Rusby et al., 2008), and a quality lens (Doherty et al., 2006; Hughes-Belding et al, 2012), PEC theory is a suitable choice for this study for several reasons. First, it is an appropriate choice because PEC theory challenges the dominant structures of economic production and consumption and questions gender roles within capitalist sites of production (Bedford \& Rai, 2010; Cameron, 2006). Whereas traditional economics analyze market economy, and the circular flow of production and consumption between household and the market, the feminist economics also examine these economic processes within household while illuminating gendered nature of social reproductive labour (Folbre, 2006). The participants in this study are care workers that engage in providing care inside their residences, and thus are simultaneously engaged in economic production and social reproduction activities. PEC theory can provide an analytical lens through which the interaction of these two activities can be observed.

Second, PEC theory aims to expose the marketization of care and the policies that encourage care work by way of a capitalist economy (Williams, 2011). The UHBC providers in this study operate within the grey market economy, which is characterized by the absence of regulatory structures (Barber, 2004). PEC theory can aid the understanding of participating providers of UHBC through illuminating relationship of the carer and the commodification of care services that summon the market principles that encompass maximization of profit, potentially leading to low quality of care (Held, 2006). 
Third, as a feminist framework, PEC theory is sensitive to women's experiences, particularly in unregulated markets or in unpaid cites of production, allowing "for traditionally marginalized and silenced voices to be heard" (Hankivsky, 2011). PEC scholars have elucidated women's experiences within the care economy by bringing in women's subjectivities into the field of economics that has been widely accepted as men's domain (Folbre, 2006; Razavi, 2007). Illuminating women's voices is particularly important to this study, as the portrayal of UHBCs by the media is predominantly negative and void of voices of women who operate UHBCs.

Furthermore, the PEC theory is built upon ethics of care, as a moral approach, and recognizes the interdependency between the carer and the cared, as well as the relative aspect of care built on trust between the giver and the receiver of care (Mahon \& Robinson, 2011; Tronto, 2011). The PEC theory emerged to address some of the consequences of globalization and neoliberal policies that keep placing the onus on the individual, including the responsibility for care. For example, government tax credits and cash incentives, such as the Universal Child Care Benefit (UCCB), encourage parents to access childcare privately through the market (Williams, 2011). In addition, the PEC theory addresses migration of care workers from predominantly developing countries to developed wealthy nations (transnationalization of care) and increase in cheap domestic labour in healthcare and childcare, which is highly gendered and racialized. By addressing these global trends, it illuminates the global care chains characterized by links of a migrant worker that cares for a child in a foreign country to her own children being cared for by yet another migrant worker from a different country (Yeates, 2005). Thus, the PEC scholars try to problematize the care regimes and bring the issues that the carers face into the public light (Williams, 2011). 
In other respects, PEC theory considers care economy in a general sense, and its corollary to women. For instance, PEC scholars scrutinize the policies and discourses that encourage "the development of particular form of home-based, often low-paid commodified care or domestic help" (Williams, 2011, p. 23). Utilizing the political economy of care in this study can aid in understanding complexities of unregulated home-based childcare. The following section elaborates on four key features of the PEC theory: social reproduction of care work; care work within grey markets; transnationalization of care; and solutions to address political economy of care.

\section{Social reproduction of care work}

In the context of political economy of care, a care worker is conceptualized as a labourer that is involved in physical and emotional labour of caring for someone, and encompasses a range of social reproduction activities (Yeates, 2005). Social reproduction can be seen as a "biological production of the species... and ongoing reproduction of the commodity labour power" (Bakker \& Silvey, 2008). In addition, social reproduction operates in perpetuating dominant ideologies and cultural tendencies in order to keep the dominant social relations in a status quo (Bedford \& Rai, 2009).

Historically, social reproductive labour has been a women's work performed in a private, domestic sphere and has been a part of the "dominant ideology of the capitalist political economy" (Luxton, 2006; McGrath \& DeFilippis, 2009, p. 68). Attached to this notion of feminized private sphere is the assumption that social reproductive labour (care work) is innate to women, suggesting that women should have a complete responsibility for care (Gabriel, 2011). Although the increase of women participation in labour market has to some extent shifted social reproduction from household economy to the state and the market economies that include 
various institutions such schools and childcare, the expectation that women are responsible for social reproductive activities remains (Folbre, 2006; McGrath \& DeFilippis, 2009). By virtue of being women's labour carried out in a household without remuneration, activities of social reproduction conducted within the market mirror sexual divisions of reproductive labour done within the household and thus become devalued (Yeates, 2005).

\section{Care work within grey markets}

Another feature of PEC theory is its examination of a grey market economy. A grey market can be defined as "unofficial but not illegal system of selling goods" (Barber, 2004), encompassing fewer regulations and thus, less interference from the state. Due to the gendered nature of care economy and devaluation of care work, the care economy often operates within the grey markets that are either unregulated or have fewer regulations that the regulated market economy. Thus, unregulated home-based childcare, childcare by a nanny, elder care and women working in sex trade are some examples of sites where PEC operates.

Grey markets are made possible by the prevalence of the neoliberal state policies that encompass restructuring of the state's responsibilities. This transformation comprises of transferring the state's responsibilities for human well-being and the economy to corporations, as well as involves the invoking of entrepreneurialism in individuals who are now, under neoliberalism, self-reliant and autonomous (Davies \& Bansel, 2007). As such, the state imposes the responsibility for social reproduction (care work) onto "private households, where it is accomplished through unpaid household labour or purchased" (Luxton, 2006, p.39) through the market, regardless of its forms. PEC scholars reason that the provision of care through a (grey) market is problematic because transactions of care purchases follow the norms of the market 
economy that subsume individual economic gains through maximum production for the minimum cost (Held, 2006).

Moreover, the absence of government oversight results in precarious work conditions and low-cost care markets (Razavi, 2007). The lack of regulation of some sites of care economy could potentially strip care providers of workers' rights, particularly if the care provider has a precarious immigration status. For instance, a live-in caregiver with a work visa has little bargaining power over her wage and work conditions, because she might fear the consequences of negotiating her wages with her employer (Razavi, 2007).

Furthermore, the provision (or the absence) of certain types of social policies such as the UCCB, "carries implicit objectives and significant consequences, supporting particular models of the family and of gender relations" (Razavi, 2007, p. 2). Thus, the lack of government policies that address the work of social reproduction, for instance, a national childcare system, result in perpetuating of the care economy where the responsibility for social reproduction lies within private sphere or the market. Care work done privately or through the market is beneficial to the state, as it creates a potential future work force, and compared to public expenditures it costs little (McGrath \& DeFilippis, 2009).

The state's cordial relationship with the markets is part of neoliberal restructuring of social policies (Bezanson \& Carter, 2006). Under the slogan 'freedom of the market', neoliberal state seeks to expand existing markets, and create new markets where they have not been before (Connell, 2010). The discourse of neoliberalism posits that the market is best at providing services and goods to the people, and that it is both more economically and time efficient then the public sector. This leads to privatization of public services, deregulation, and commodification of things that would not have been considered as commodities (Connell, 2010). 
Coincidently, commodification occurs in the sphere of caring for children resulting in lowering the wages of care workers, and lowering the quality of childcare provision (Razavi, 2007).

\section{Transnationalization of care}

Transnationalization of care is another aspect of the political economy of care theory. It is characterized by the migration of women from developing countries into wealthier countries in order to engage in care work. The migrant women typically leave their families including children in their home countries. If they have young children, they are cared for by either other family members, older siblings or yet another migrant care worker from a poorer country. Arlie Hochschild termed this phenomena 'global care chain', describing it as "an older daughter from a poor family who cares for her siblings while her mother works as a nanny caring for the children of a migrating nanny who, in turn cares for the child of a family in a rich country" (Hochschild, 2000, p. 131, as cited in Yeates, 2005, p. 229). The movement of care labour encompassed by care chains typically takes place from global South to global North, from poverty-ridden countries to wealthier countries. This movement reveals the lack of material resources in a migrant's home country, resulting in an unequal distribution of care resources in the developing and the wealthy countries (Yeates, 2005). In the political economy the global care chains can be viewed as "trade mechanisms for importing/exporting care labour" (Yeates, 2005, p. 230).

\section{Solutions to address political economy of care}

By exposing the economic processes and the gendered nature of care economy, PEC scholars attempt to bring forward solutions that can address the current trends within care economy. The presence of better social policies is one such solution. Nation states need to address their own family policies and, on international level, global trends of migration. 
Governments need to recognize how different state policies "shape the employment of homebased care workers" (Williams, 2010, p. 389) examining migration rules and regulations, as well as care and employment policies pertaining to work-life balance. For instance, well-developed public care policies can promote gender equality through allowing women to participate in labour market, whether a woman is a giver or a purchaser of care. In addition, public care policies validate care work, increasing its value and by that improving care workers' economic conditions (Razavi, 2007).

Furthermore, state policies need to address the precarious status of migrant care workers extending the rights of citizenship to them (Tronto, 2011). However, immigration and citizenship policies need to be addressed together by the host countries and the countries supplying care labour. Such policies can take shape in multilateral agreements working together to ensure the migrant care workers have access to labour protection rights and basic human rights to safety and freedom (Razavi, 2007; Williams, 2010).

Another solution is for the domestic care workers to become organized and form coalitions (Razavi, 2007). This will enable them to advocate for their rights, as well as increase their bargaining power. However, such organization of domestic care workers cannot take place if some of the policies outlined above are missing. If the care workers are not protected by the governments first, then they risk a further exacerbation of power imbalance within their workplace- the household.

In this chapter, I outlined four features of PEC theory that focused on social reproduction, grey markets, transnationalization of care, and ways PEC scholars address care economy. Although PEC theory aims to problematize care regimes, it values the voices of women that operate within care economy. Moreover, it does not simply offer critique, but provides solutions 
to care issues at global and state levels. Because the care workers in this study are women, who operate within a grey market economy, PEC theory will provide a valuable lens through which their work as UHBC providers can be analyzed. 


\section{Chapter Three: Literature Review}

The literature review for this study was conducted at the inception of the study in order to scope recently available scholarly works about home based childcare whether regulated or unregulated. This chapter aims to illustrate the parameters of research on home-based childcare in general and identify gaps in literature. The review of literature was conducted by examining topics researchers explore in regard to home-based childcare in general. Most of the research reviewed here inquired into regulated home-based childcare (RHBC), and only two studies inquired into unregulated home-based childcare (UHBC). The review is organized by the questions researchers ask about R/UHBC addressing the following topics: home-based childcare providers; quality in home-based childcare, and benefits of home-based childcare.

\section{Home-based childcare providers}

All of the studies reviewed in this section were conducted on RHBC. In trying to understand home-based childcare, researchers have focused on providers, revealing factors that motivated them to operate RHBC, experiences of stress and relationships with parents, and their sense of their own professionalism. Armenia (2009) reported on RHBC providers motivations for starting a RHBC. She found that the primary reason for women to begin to provide childcare in their homes is that they wish to stay at home with their children or their grandchildren. Because many providers might not be able to be "stay-at-home moms," operating a RHBC was seen as a viable option for supplementing family income. However, Armenia (2009) although confirmed the assumption that some providers are typically motivated by motherhood, she demonstrated that it is not the only motivator. Other motivating factors included wanting to work from home, making an income, and giving back to the community. Interestingly, Armenia (2009) revealed that Caucasian RHBC providers were more motivated by the continuing traditional 
motherhood role, whereas African-American RHBC providers were motivated by the need to contribute to their communities, and provide care for children of family and friends.

Regardless of the influences on establishing a RHBC, Butler and Modaff's (2008) study revealed that RHBC providers experience stress because of certain tensions due to blurred lines between home and work. For example, providers reflected on how their workday, caring for others' children (and sometimes their own too), continued through the evening through caring for their own children and their spouses in the form of preparing dinner, cleaning up and helping their children with homework. For these providers, home-based business affected the family dynamics, especially so when the husband would not recognize the labour intensive work his wife does during the day. Butler and Modaff (2008) revealed a gendered assumption about domestic work, as they "reported that spouses often regarded their (RHBC providers) days as less difficult because they were taking care of children in the luxury of their own homes" (Butler \& Modaff, 2008, p. 243).

Furthermore, UHBC providers in Butler and Modaff's (2008) study identified relationship with parents as a point of stress. Often the providers and the parents had differing ideologies in regards to child rearing practices. It appears that the RHBC providers felt that they needed to supplement parenting by providing nutritious foods, exercise, and activities, such as gardening that they think parents would not normally do with their children. The providers' embodiment of mother figure was exacerbated by them critiquing mothers that left their children in providers' care for too long. In addition, parent-childcare provider tensions developed over perceived relationships of the childcare provider with the children. The providers reported that parents often felt jealous of child/caregiver attachment. 
In contrast, a study conducted by Freeman (2011) of RHBC providers relationships with community found that providers were involved actively in their communities as liaisons between families and schools. The providers reported supporting parents' goals for their children as well as having developed long-term relationships with families. Whereas the RHBC providers in Butler and Modaff's (2008) study functioned as substitute mothers, RHBC providers in Freeman's (2011) study took on a partnership role. From these two studies, it is unclear why the providers' experiences differ when it comes to the relationship with parents. One can speculate that demographics they served and the levels of providers' education might have an effect on these relationships.

Furthermore, the authors of these two studies extracted two interrelated concepts: perception of one's professionalism (Freeman, 2011) and "feeling unappreciated" (Butler \& Modaff, 2008, p. 248). For providers in Freeman's (2011) study, professionalism equated to acting like a teacher. This notion of professionalism is understandable, as the public often perceives home-based childcare providers as babysitters (Freeman, 2008). These RHBC providers wished to relay to the parents and the school teachers through their practice that the children in their care learn. In Butler and Modaff's (2008) study, providers felt unappreciated when parents violated their RHBC policies. This further exacerbated tensions with the parents. For these providers, the violation of policies was a sign of disrespect, which undermined their feeling of professionalism. Again, perhaps these providers were viewed more as babysitters who did not deserve the same level of respect, as opposed to being viewed as teachers, like the providers in the Freeman's (2011) study.

The theme of professionalism also emerged in the Lanigan's (2011) study, in which the providers reported feeling a sense of professionalism after completing professional development. 
The home-based childcare providers distinguished themselves from babysitters after engaging in professional development. This sense of professionalism affected the relationship dynamics with the parents in a way that the parents began to view them as authorities on specific knowledge. However, before engaging in professional development, the providers often felt that they were being regarded as babysitters by the parents and licensing personnel (Lanigan, 2011).

Moreover, one important finding in Lanigan's (2011) study was the way the RHBC providers viewed their role in respect to early childhood education field. The providers found that they provided services distinct from centre-based childcare but by no means, "less professional or less dedicated to providing quality childcare" (Lanigan, 2011, p. 406). They felt strongly about the essence of their philosophy to provide home-like care for the children in mixed age environment, something that centre-based care is not always able to do. They think of themselves as "unique in terms of operation and challenges" (Lanagan, 2011, p. 406) and the benefits they can provide the children and families.

\section{Quality in home-based childcare}

Once again, the studies reviewed in this section reflect RHBC sector. Quality in homebased childcare, whether regulated or not, has been a pertinent topic in the literature presented here. In their study of RHBC, Doherty, Forer, Lero, Goelman, and LaGrange (2006) used the Family Day Care Rating Scale (FDCR), self-reporting questionnaires and interviews in order to understand factors that contribute to quality of UHBCs. In general, they found that many providers did not provide an adequately stimulating environment for the children, albeit the RHBC was physically and emotionally safe. More specifically, Doherty et al. (2006) found provider's commitment to one's profession and a professional approach to one's work - termed intentionality — as a predictor of quality in RHBC. In fact, they emphasized intentionality as 
being pivotal to quality in RHBC. Moreover, the authors found that early childhood education (ECE) specific education affects intentionality. This could mean that RHBC providers that have ECE specific education are more likely to consider their RHBC a long-term commitment. Consequently, providers who demonstrated commitment to providing childcare as a career choice exhibited professionalism and thus had higher quality RHBC (Doherty et al., 2006).

Similarly, Hallam, Bargreen and Ridgley (2013), who analyzed secondary data from evaluations by Tennessee's Child Care Evaluation and Report Card Program, investigated the quality of the RHBC in relation to providers' ECE specific education. They found that ECE specific education positively affected quality of RHBC in comparison to post-secondary education in other fields. The authors specified that the ratio of non-ECE trained providers to ECE trained is still high. For that matter, they highlighted the importance of professional development for RHBC providers to ensure quality of care.

Although professional development can increase quality in RHBC, due to the nature of RHBC, providers may have difficulty not only accessing professional development but also allocating time for it. Rusby, Jones, Crowley, Smolkowski and Arthun (2013) also asserted the importance of RHBC providers' participation in professional development. They conducted a study that focused on predictors of home-based childcare providers' participation in professional development. What they found was that home-based childcare providers were likely to participate in professional development program that included the workshops and follow up activities depending on "demographic variables, working conditions... training, and interpersonal factors such as stress and depression" (Rusby, Jones, Crowley, Smolkowski \& Arthun 2013, p. 450). 
Rusby et al. (2013) revealed that professional development that is geared towards RHBC childcare providers is key to their participation. For example, the authors reported that the attendance of a professional development workshop depended on the time of the workshop, professional development credit, opportunity to study from home, and informal support groups (Rusby et al., 2013). Unfortunately, Rusby et al. (2013) found that providers with higher education were more likely to complete professional development workshops and engage in follow-up activities. This is problematic because, as earlier indicated in this review, education plays a large role in quality of RHBC. When RHBC providers lack ECE specific education, professional development can mitigate the lack of knowledge and increase overall RHBC quality.

Quality of RHBC has been measured in terms of the presence of regulable features by Hughes-Belding, Hegland, Stein, Sideris and Bryant (2012). They defined regulable features as structural characteristics that are usually mandated by childcare regulations, such as years of education, professional development and years of experience. The authors revealed that the presence of such variables in RHBC positively correlated with overall RHBC quality. However, they pointed out that structural characteristics, although important, are not sufficient to ensure quality. Thus, Hughes-Belding et al. (2012) correlated providers' child rearing beliefs with RHBC quality. They found that providers whose beliefs about children reflected child-centered ideals offered a higher quality of childcare services then the providers with didactical beliefs. Unlike Doherty's et al. (2006) study where they stressed the importance of intentionality (commitment to the profession), Hughes-Belding et al. (2012) found that professional motivation, which they defined as when providers approach their work as a career, to have no impact on overall quality. 
Furthermore, Raikes, Raikes and Wilcox (2005) confirmed that regulation affects overall quality of RHBC services by stating, "Regulation — and things that go with it such as specialized training requirements and visits by state licensing personnel may help providers achieve higher global quality" (Raikes et al., 2005, p. 180). Although Raikes et al. (2005) also confirmed the importance of education of the RHBC provider when it comes to the overall quality of RHBC, their study pointed out the relationship between provider's education and regulation of RHBC. Interestingly, the providers who have education but are subject to weaker regulations displayed sensitivity towards children. Thus, in this case regulation may not play as important role as education. One of their important findings was that children from low-income families that attend RHBC where the provider does not have education were at risk for less sensitive care, in addition to being exposed to poorer childcare quality.

\section{Benefits of home-based childcare}

This section presents research that highlights the benefits of UHBC. The studies reviewed here are the only two studies within this literature review that focus on unregulated childcare sector. However, the researchers' exploration of UHBC came through parents' perceptions, rather than those of UHBC providers. The authors of these studies have delineated parents' reasons for choosing UHBC, and thus illustrated ways in which UHBC meets parent's needs.

McKinley's (2010) study discussed how costs of regulated childcare affect low-income parents' childcare choice, as women that use UHBC identified affordability as one of the reasons for choosing UHBC. Some mothers expressed that their income would be cancelled out if they would pay for regulated childcare. An UHBC offers a cheaper option, which allows to keep their expenses manageable. Furthermore, some mothers expressed flexibility in payment, in as much that they do not have to pay for a child's missed days due to illness, and Christmas or March 
breaks. The flexible fee structure allows the families to further reduce their childcare expenses, in contrast to the centre-based childcare where the fee structures are more rigid, and the mothers would have to pay for any days missed by their children.

Nonetheless, some parents who do not face the issue of affordability might also use UHBC. McKinley (2010) cited a lack of availability of childcare spaces as a reason some women had chosen UHBC. For example, one of the participants in this Canadian study shared a valuable insight: the maternity leave benefits end around the child's first birthday, thus parents are required to seek childcare for a 12 months old child; yet, many centres accept children after they become 18 months old. Those centres that do accept children who are under 18 months of age have long waiting lists. Other reason includes flexibility in UHBC operating hours. Parents who work irregular shifts found that the UHBC arrangement accommodated them better than centre-based childcare. In all, it seems that, these parents chose UHBC because the regulated childcare could not accommodate their childcare needs.

Additionally, some parents seek UHBC because they prefer their children to be cared for in a home setting. Huang (2007) interviewed eight mothers and five fathers (all of Caucasian background) to gain understanding of their perspectives about UHBC. She found that the overarching reason for parent's choice of UHBC was the value of continuity. Huang (2007) found that "parents sought continuity of their own care and environment that resembled their own care at home" (p.121). Parents sought a UHBC provider that would act as a substitute mother who treats their children with affection, and gives "special" attention, or prioritizes attention for their children. And like a mother, the provider had to have an unconditional acceptance of their children, regardless of child's temperament or dispositions. Similar to the preference for continuation of home environment, parents had a preference for continuation of 
their child-rearing practices and values. Home-based childcares can better accommodate parents like the ones in Huang's (2007) study than a centre-based program where the environment feels institutional-like, group sizes are larger, and parent/staff relationship is defined by professional boundaries (thus the staff might not be able to accommodate some parents).

Overall, the literature on home-based childcare revealed that researchers primarily focus on regulated home-based childcare. This is not surprising because unregulated providers of childcare services might be a harder group to reach. Studies that inquired into unregulated homebased childcare did so indirectly by interviewing parents about their experiences with UHBC (Huang, 2007; McKinley, 2010). Research inquiring into RHBC primarily focuses on the quality of home-based childcare often comparing its quality to centre-based care on global quality, staff qualifications in early childhood education, engagement in professional development (Doherty et al., 2006; Hallam et al., 2013; Hughes-Belding et al., 2012; Lanagan, 2011; Rusby et al., 2013). Some research is available about providers' motivations to operate RHBC (Armenia, 2009) and regulated providers' experiences with operating their home-based childcare (Butler \& Modaff, 2008; Freeman, 2011; Lanigan, 2011).

The review of the literature revealed a few gaps. The experiences of UHBC providers remain under-reported in North American literature. Many studies investigating RHBC take place in United States, where regulatory standards are not only different from Canadian standards, but also vary dramatically across states. Considering that most children in Canada are in unregulated care, the UHBC sector remains under-researched, which results in a significant gap in knowledge. Although this group of providers is difficult to research because they are not listed in any type of database, it is important to find out the thoughts and perceptions of the UHBC providers because of the contribution they make towards caring for children. Thus, the 
current study aims to address this gap by inquiring about UHBC through providers' perceptions. Moving forward, the guiding research question is What are operators'perceptions of providing unregulated home-based childcare?

This study has a potential of contributing to the field of early childhood education and care a snapshot of UHBC sector in a Canadian context. The study can unearth perspectives of some of the providers about providing care for young children, and begin to understand their work through the critical lens of the political economy of care theory. As a small-scale study, it can serve as a basis or a starting point for a much larger, more encompassing research undertaking that could involve a larger proportion of unregulated home-based childcare sector. 


\section{Chapter Four: Methods}

The purpose of this study was to examine unregulated home-based childcare (UHBC) providers' perceptions about their work, in order to gain a snapshot of unregulated childcare sector. Initially, I wanted to inquire about experiences of only Russian speaking operators of UHBC because I have had personal experience with Russian speaking providers who have cared for my daughter, and thus wished to explore this niche of UHBC sector. However, I have encountered recruitment challenges that will be described further in this chapter. As a result, I had broadened my sample to encompass English-speaking operators of UHBC as well. Consequently, my research question had to be amended from focusing only on Russian speaking providers to all providers of UHBC. The research question guiding the study was What are operators' perceptions of providing unregulated home-based childcare?

The nature of this research questions required that I gather detailed views from the participants in order to provide me with a fuller picture of their experiences (Creswell, 1998). In order to understand participants and answer the research question, qualitative approach to research design was a suitable choice. A qualitative approach allows the learning of a phenomenon by focusing on participants' meanings, which allows for a holistic representation of a phenomenon (Creswell, 2014). Because this study focuses on UHBC providers' perceptions, a qualitative approach allowed me and the participants to engage in a meaning making interaction; and thus, allowed me to better understand their roles as UHBC providers (Van den Hoonaard, 2012). A qualitative approach enabled me to extrapolate meaning from the data through thematic analysis, and to explore the issue based on the participants' ideas, rather than my own.

Furthermore, a qualitative study allows for researcher's reflexivity. Reflexivity is one way to ensure that the researcher understands or is aware of her biases and values before 
commencing the research project, as well as while conducting the study and interpreting the data (Dowling, 2008). I have a vested interest in this topic due to my own experience as a user of an UHBC. A qualitative approach allowed me to delve into the research without having to ignore my own experiences and knowledge and, instead use them to connect with the providers on a personal level. It is my assumption that because I was able to connect with home-based childcare providers as a consumer of such services, the participants were more inclined have a good rapport with me.

\section{Sample and Recruitment}

In this study, I employed a purposeful sampling technique (Creswell, 1998; 2014). This sampling technique works best in qualitative studies because it allows the researcher to select her participants with clear criteria in mind (Creswell, 1998). Some of the aspects of purposeful sampling techniques that I utilized are criterion sampling where all participants need to meet a certain criteria, opportunistic sampling, which allows any eligible participant to engage with me; and, snowball sampling that can provide participants through other participants or word of mouth (Creswell, 1998).

The recruitment of participants was realized through on-line and physical flyers and targeted both Russian and English speaking population. The recruitment was carried out in four stages. First, the physical flyer was designed in both English and Russian languages for an ease

of understanding. The information on the flyer included the purpose of the research, eligibility criteria, my approach, benefits or incentives for participation and my contact information. The Russian language flyer was posted in geographical locations in the Greater Toronto Area where a predominantly Russian speaking population resides. The flyer was posted in places such as public parks, bus stops and public announcements boards. The locations for posting a flyer were 
determined by me, as I am also Russian speaking and familiar with the Russian speaking neighbourhoods.

Second, an on-line recruitment for a Russian speaking sample was conducted through a Facebook group page, Toronto Mommies (TM). This group is private and one has to be a member in order to participate in the group's discussions and observe members' posts. At the time of the recruitment, TM had 2700 members. Although I was a group member prior to conducting this study, I did not communicate on a regular basis with other members. In addition, I asked the TM group's administrator to post the flyer on their group's page. The flyer in its digital form was posted on the groups' page. Recruiting through Facebook can be an effective method of recruitment, because the information has a potential to reach many people.

The third stage of recruitment was conducted through a snowballing technique, where the author's friends and family members were made aware of the study I planned to conduct. Some friends and family members had the opportunity to speak about this study with the people they thought might be interested. During this type of recruitment, family members were explicitly told about ethical recruitment, such as to provide information to potential participants but not ask or force them to participate as a favour. Although this type of recruitment can provide an access to participants that due to familiarity with the family member might be more open during the interview, I could not have been certain that the participant's involvement is truly voluntary. To alleviate such risk, during the interview, I emphasized that the participant could withdraw from the study at any point of the study.

The fourth stage of recruitment had to be conducted due to the lack of Russian speaking participants interested in the study. I expanded study population to include all UHBC providers. The English version of the recruitment flyer was e-mailed to home based childcare providers that 
advertised their home childcare on-line advertisements websites. This recruitment strategy proved to be more fruitful, and produced the majority of participants. The individuals that were interested in participating in the study e-mailed me to express their interest. I contacted the interested individuals and asked them questions pertaining to the selection criteria. Each participant was asked whether she was the owner of the home based childcare and if her home based childcare was not overseen by a licensed agency. The number of participants recruited for this study was limited to five to ten because of the short time frame allotted for this study.

In total ten people expressed interest in this study. However, one person did not fit the selection criteria — she was an assistant at a home childcare and not the owner. Two people expressed the need of the inquiry that this study entails; however, said that they could not find time for the interview. In all, seven UHBC providers participated in this study. The summary of participants' characteristics is offered in Table 1.

\section{Recruitment challenges}

I have encountered a few recruitment challenges when recruiting from Russian speaking population. My initial recruitment strategy of posting flyers in Russian ethnic neighbourhoods and Facebook group provided no response. It is my assumption that Russian-speaking people find it difficult to trust strangers. As in an ethnographic study, building a rapport with such a population is crucial for gaining access into their day-to-day life experiences. Because of the short time lines for this study, a decision was made to expand the selection criteria, which was to include English speaking independent home based providers. Although recruitment of Englishspeaking home based childcare providers was more effective, the desired number of participants $(\mathrm{N}=10)$ was not reached. After public on-line advertisement and recruitment through e-mail, seven participants volunteered for this study. 
Table 1. Characteristics of UHBC participants

\begin{tabular}{|c|c|c|c|c|c|c|c|}
\hline & Emily & Linda & Patricia & Hannah & Ava & Michelle & Vera \\
\hline Age Range & $25-34$ & $45-54$ & $35-44$ & $45-54$ & $45-54$ & $35-44$ & $45-54$ \\
\hline Gender & $\mathrm{F}$ & $\mathrm{F}$ & $\mathrm{F}$ & $\mathrm{F}$ & $\mathrm{F}$ & $\mathrm{F}$ & $\mathrm{F}$ \\
\hline Ethnicity: & Caucasian & Caucasian & Caucasian & Caucasian & Caucasian & Caucasian & Caucasian \\
\hline Marital Status: & Married & $\begin{array}{l}\text { Common } \\
\text { law }\end{array}$ & Married & Married & Married & Married & Married \\
\hline What would you say your job title is? & $\begin{array}{l}\text { Day care } \\
\text { provider }\end{array}$ & $\begin{array}{l}\text { Home } \\
\text { daycare } \\
\text { provider } \\
\text { Wellness } \\
\text { Coach }\end{array}$ & $\begin{array}{l}\text { Home } \\
\text { daycare } \\
\text { provider }\end{array}$ & $\begin{array}{l}\text { Home } \\
\text { childcare } \\
\text { provider }\end{array}$ & RECE & $\begin{array}{l}\text { Daycare } \\
\text { provider/o } \\
\text { wner } \\
\text { operator }\end{array}$ & $\begin{array}{l}\text { Home } \\
\text { childcare } \\
\text { owner }\end{array}$ \\
\hline Education and/or Qualifications & $\begin{array}{l}\text { BA in } \\
\text { English } \\
\text { Literature } \\
\text { and } \\
\text { Drama } \\
\text { Diploma } \\
\text { in Child } \\
\text { and Youth } \\
\text { work }\end{array}$ & $\begin{array}{l}\text { Diploma } \\
\text { Nursery } \\
\text { Nursing } \\
\text { (UK) }\end{array}$ & $\begin{array}{l}\text { Diploma in } \\
\text { ECE }\end{array}$ & $\begin{array}{l}\text { College } \\
\text { Diploma, } \\
\text { Childcare } \\
\text { related } \\
\text { workshops }\end{array}$ & $\begin{array}{l}\text { Diploma in } \\
\text { ECE }\end{array}$ & $\begin{array}{l}\text { BA Fine } \\
\text { Arts and } \\
\text { Cultural } \\
\text { Studies } \\
\text { Diploma } \\
\text { in Design } \\
\text { Fundamen } \\
\text { tals in the } \\
\text { process of } \\
\text { getting } \\
\text { Diploma } \\
\text { in ECE }\end{array}$ & $\begin{array}{l}\text { Post- } \\
\text { Secondary } \\
\text { Diploma } \\
\text { from } \\
\text { Ukraine }\end{array}$ \\
\hline Years in business & 4 years & 2 years & 7 years & 8 years & 7 years & 6.5 years & 2 years \\
\hline
\end{tabular}




\begin{tabular}{|c|c|c|c|c|c|c|c|}
\hline Parent Fees per child & $\begin{array}{l}\text { \$1400 } \\
\text { /month }\end{array}$ & $\begin{array}{l}\$ 1200 / \\
\text { month }\end{array}$ & $\begin{array}{l}800 / \\
\text { month } \\
\text { B/A: } \$ 15 / \\
\text { day }\end{array}$ & $\begin{array}{l}\$ 840 / \\
\text { month }\end{array}$ & $\begin{array}{l}\$ 696 / \\
\text { month }\end{array}$ & $\begin{array}{l}\$ 800 / \\
\text { month } \\
\text { B/A: } \\
\$ 25 / \text { day }\end{array}$ & $\begin{array}{l}\$ 900 / \\
\text { month }\end{array}$ \\
\hline Perceived income ${ }^{1}$ & $\begin{array}{l}\text { A little } \\
\text { above } \\
\text { average }\end{array}$ & $\begin{array}{l}\text { Above } \\
\text { average }\end{array}$ & $\begin{array}{l}\text { Below } \\
\text { average }\end{array}$ & $\begin{array}{l}\text { Slightly } \\
\text { above } \\
\text { average }\end{array}$ & $\begin{array}{l}\text { Below } \\
\text { average }\end{array}$ & $\begin{array}{l}\text { Below } \\
\text { average }\end{array}$ & Average \\
\hline $\begin{array}{l}\text { Number of the provider's children in } \\
\text { UHBC }\end{array}$ & 2 & No & $\begin{array}{l}1 \text { child in } \\
\text { B/A school } \\
\text { care }\end{array}$ & No & No & 1 & $\begin{array}{l}1 \text { child in } \\
\text { B/A } \\
\text { school } \\
\text { care }\end{array}$ \\
\hline Ages of children admitted & $\begin{array}{l}6 \text { months } \\
\text { to } 4 \text { years } \\
\text { old }\end{array}$ & $\begin{array}{l}1-2 \text { year } \\
\text { olds } \\
\text { cohort }\end{array}$ & $\begin{array}{l}9 \text { months to } \\
12 \text { years old }\end{array}$ & $\begin{array}{l}\text { 1 to } 4 \text { years } \\
\text { old }\end{array}$ & $\begin{array}{l}0 \text { to } 6 \text { years } \\
\text { old }\end{array}$ & $\begin{array}{l}1 \text { to } 12 \\
\text { years old }\end{array}$ & $\begin{array}{l}1 \text { to } 4 \\
\text { years old }\end{array}$ \\
\hline Location & GTA & GTA & $\begin{array}{l}\text { Durham } \\
\text { Region }\end{array}$ & $\begin{array}{l}\text { Halton } \\
\text { Region }\end{array}$ & $\begin{array}{l}\text { Southweste } \\
\text { rn Ontario }\end{array}$ & $\begin{array}{l}\text { Durham } \\
\text { Region }\end{array}$ & GTA \\
\hline
\end{tabular}

Note ${ }^{1}$ Perceptions of an average income in comparison to childcare centre staff in Ontario whose average remuneration is $\$ 17.29$ /hour (YBWSC, 2013 


\section{Setting}

The setting of the study depended on where participants preferred to be interviewed. Ideally, I would have liked to have interviewed participants in their home-based childcare, as it is their natural setting and where they may feel more comfortable answering questions, as opposed to undergoing an interview in a neutral space. In addition, being present in their natural setting would have given me the opportunity to observe their environment. Although I did not intend to use these observations for data analysis, this would have provided an opportunity to probe deeper for meaning, which could have led to a better understanding of their experiences. However, I understand that many people feel reluctant letting a stranger into their homes. Only one interview was conducted at a participant's home childcare. Two interviews were held at a neutral location and four interviews were conducted over the phone. Although phone interviews have their limitations such as difficulty to build rapport and inability to read body language, they allow for participant anonymity and are cost effective for the researcher when the participants inhabit different geographic locations (Hughes, 2008).

\section{Ethical Considerations}

A few ethical considerations had to be made in order to move forward with this study. Participation in this study involved moderate risks. The participant population for this study is engaged with a vulnerable population — children. They have a moral responsibility to provide services that are free of child abuse and neglect, as well as have a responsibility to provide care in accordance with the law, as stated in the "Day Nurseries Act" (1990). As a researcher coming from Early Childhood Studies program, I am bound by civil and professional duties to identify and report a breach of law if I have reasonable grounds to suspect that children in the care of any of my participant are being abused or neglected (Government of Ontario, 2010) or if any of my 
participants are caring for more than the allowed five children plus their own. This is a significant risk to potential participants because some may not be aware of the Ontario rules in regards to home childcare, whereas others may engage in behaviour management techniques that are not considered acceptable but might be culturally appropriate to that participant. Consequently, participation in this study may have involved a potential legal threat to participants.

In order to mitigate the risk of legal threat, the consent form clearly stated my civil and professional duties to report a breach of law. Any potential participant that read over the consent form had a choice to discontinue their participation. In addition, the participants were encouraged to ask questions about any clause in the consent form. All participants disclosed the number of children they lawfully cared for. All participants except one were interviewed outside their home-based childcare, thus I could not have made an observable deduction of the violation of law.

Although my ethical obligations are important, they inhibit the chances for all representing members of the population to participate in the study. For instance, a homechildcare provider that operates illegally under the "Day Nurseries Act" (1990) has a potential to illuminate this aspect of the childcare sector. Moreover, participants who may be unsure of the appropriateness of their actions or would not want to be judged on the appropriateness of their actions would also self-exclude from the study. Consequently, the individuals that volunteered to be a part of the study formed a homogeneous group. However valuable the insights they provided may be, they might be only representing a fraction of the home-based childcare sector.

\section{Data Collection}


In order to find out how home-based childcare providers perceive their line of work, I used qualitative interviews that were conducted in person or over the phone, one-on-one (Creswell, 2014). In a one-on-one interview, the participant may feel more comfortable sharing her experiences than in a focus group (Creswell, 1998). However, this also can be an impediment to an interview if the participant is shy or not comfortable (Creswell, 1998). Six interviews were conducted in English, and one interview was conducted in Russian in order to ensure that the participant understood the questions and can answer comfortably. I adopted a semi-structured interview protocol that contains 16 open-ended questions and 11 demographic questions (for an interview protocol, see Appendix A). Open-ended questions allow the participant to impart their own meaning and provide the researcher with a range of information that might lead into new theoretical waters, as well as allow the researcher to probe for further information (Archer \& Berdahl, 2011, p. 89). All interviews were audio recorded in order to ensure accuracy of information during the analysis phase.

\section{Data Analysis}

During data analysis, I used categorizing strategy, which involves the generating of codes through open coding (Maxwell, 2009). As I was examining interview data, I looked for the salient categories of information that reflected the perceptions of my participants about providing care (Creswell, 1998). Further, when the initial set of categories were developed, I examined the interview data again through the established categories. The interpretation of data was heavily rooted in my theoretical framework, the political economy of care (PEC). PEC theory recognizes and values women's voices and experiences in the context of current political and economic milieu. However, it also challenges the interconnected relationship between women's 
experiences of care work and political economy. This results in deeper understanding of the complexities that weave through everyday individual experiences.

\section{Delimitations and Limitations}

The limitations of this study pertain to the sampling method, the number of participants involved, characteristics of the participants, and the language of one interview. First, I used purposeful sampling technique for this study (Creswell, 2014). This sampling technique may not have provided an adequate representation of the UHBC providers. Second, due to my method of recruitment, the providers that contacted me might have had a certain disposition towards participating in research, for example, open minded, curious, and open to new experiences. Thus, many voices of UHBC providers might have been excluded. The third limitation is the possibility of the interviewer effect where the participant seeks to please the researcher by providing answers that he/she think the researcher will approve of (Archer \& Berdahl, 2011). Although my sense of the interviews indicated openness on the part of participants, I do not have the ability to verify the information provided by the participants. Finally, more than half of the interviews were conducted over the telephone. This interviewing strategy, although cost effective, can provide fewer opportunities for probing for answers because of the inability to read body language, and difficulty in establishing rapport. However, all of the interviews conducted over the telephone were similar in length or longer than the interviews conducted in person. This could have indicated that providers interviewed over the telephone were just as likely to share their experiences as the in-person interviews. 


\section{Chapter Five: Findings}

The purpose of this study was to examine unregulated home-based childcare (UHBC) providers' perceptions about their work, in order to gain a snapshot of the unregulated childcare sector. Seven aforestated providers were interviewed individually using a semi-structured interview protocol. The UHBC providers were all Caucasian female, in the age range between 25 to 54 years old, with the majority of providers $(n=6)$ between the ages of 35 and 54 . All seven providers were married or common in law, six of them were parents to one or more child. Out of these six providers, two had their own children in their home childcare full-time; and two providers had their own children in their home childcare before and after school care. In addition to offering full-time care, two providers offer before and after school care. The parent fees charged by the participants range from $\$ 696$ to $\$ 1400$ per month per child. All of the UHBC providers had at least a college diploma, out of which two also had a university degree. Out of seven providers, three providers had Early Childhood Education accreditation, one Child and Youth Work accreditation, one received home childcare providers' training through a local organization, and one provider is in the process of acquiring ECE diploma through an online program. The geographical locations of the participants spread across Southern Ontario, representing Durham Region ( $n=2)$, Greater Toronto Area ( $n=3)$, Halton Region $(n=1)$, and Southwestern Ontario $(n=1)$.

Data collection and analysis in this study were guided by the following research question, What are the operators' perceptions of providing unregulated home-based childcare? Through interviews, the UHBC providers shared their perceptions about providing care for young children, about the benefits of UHBC, and the political forces that influence UHBC. Upon analyzing the interview data, commonalities amongst the participants' perceptions were 
observed. These perceptions were grouped into five themes: getting in the business; being called unlicensed; choosing to remain unregulated; responding to Bill 10; and being a part of early childhood education and care sector.

\section{Getting in the business}

Most of the participants shared similar motivation for opening up a home-based childcare. Many participants began providing childcare in their homes for multiple reasons such as, having a young child(ren) at home, cost of childcare services, supplementing family income, and enjoyment of caring for children. For that matter, this section will be presented by briefly describing each participant's motivations for becoming a home-based childcare provider, as well as serve as an introduction to the participants.

Ava has been an early childhood educator (ECE) for 16 years prior to opening her homebased childcare. She worked for for-profit and non-for profit organizations as a frontline ECE and as an administrator. Her experience of many structural challenges in centre-based care was the driving force behind becoming a home-based childcare provider.

For me the choice was to be able to rekindle, reclaim my passion for what I do. Because I was getting burnt out in centre care, with constant staff change overs, with constant lack of resources, shrinking pay, and all of it combined with the fact that I didn't feel like I was offering quality program that I was being pounded to the poor parents and the clientele, it drove me nuts.

In addition, Ava believed that she experienced barriers to providing the type of programming that reflected her education and care philosophy. Her passion for emergent curriculum and the Reggio Emilia approach were stifled by the bureaucratic processes of a childcare centre. Thus, she realized she would not be able to achieve her "true value of children and families and how they learn" in centre-based care.

...(I)f children learn best by hands on and being able to go out in the community, I can't 
have to jump through six weeks of paper work, in order to go on a field trip. I need to be able to sit in there and my kids being inspired by something and be able to say, ok tomorrow how about we go to children's museum, they've got some bones there we can look at dinosaur bones there. How about we go to butterfly conservatory tomorrow.

Prior to becoming a mother, Emily was a Child and Youth worker. When faced with a decision of whether or not to go back to her previous employer, Emily reasoned, "I just couldn't fathom pay for day care and look after someone else's kids, when I can look after someone else's kids right here at home." By providing childcare services in her home, she was able to remain a stay at home mom, while at the same time contributing financially to the household. Emily is the only UHBC provider in this study who provides care inside her apartment.

Similarly, Hannah decided to become a home-based provider after her second child was born. Her desire to be at home with her own children was accentuated by childcare costs for both children, even though her oldest was only in need of before and after school care. Like Emily, Hannah was faced with a decision to whether or not to go back to work, which was a demanding corporate environment. She shared, "It was stressful...I had to commute to Toronto... (and) when I'd be at home, I would be thinking about work. It wasn't how I wanted to have a family." Furthermore, Hannah had an opportunity to volunteer in her child's kindergarten class while she was on maternity leave. This experience swayed her towards becoming a home-based childcare provider.

I loved volunteering in his kindergarten classroom and I just thought, while I was there working with the kids, why did I never think about working with kids. I just never knew, it was never something that occurred to me until I had kids of my own.

Patricia told a compelling story of a family tragedy that motivated her to leave her career in municipal services and move with her family away from a large urban centre to the suburbs. She was inclined to be a stay at home mom, in order to raise her children, "So I decided then that I was going to raise my children from home, and what better way then start a home day care and 
have friends for the kids and be able to raise other (people's) kids along with them."

When Michelle first became a home-based childcare provider, she was living in Ontario's

rural area. She expressed that the special needs of her own child, challenges finding childcare,

and the cost of living were motivating factors for setting up her own home-based childcare.

Majority of us are moms that came into home daycare going, ok there's a need for this obviously, financially, as well as just for our own kids, our own kids needs, or special needs, and just as it can't be met at the licensed, and there's no spots. What we would be working for is basically our childcare if we were going to work. (Michelle)

For Linda the impetus to establish home-based childcare was her separation from her

husband, and needed the financial means to support herself and her child. Prior to separation, she was a stay at home mom. Linda shared,

I was actually looking to go back to school, to do social work or something like that. Again, I like the idea of teaching but classrooms are not for me, in that respect. But, you know, life happens, and this happens and so I opened up my home day care.

Finally, Vera began to provide childcare services for the enjoyment of being a carer, "I always wanted to have a lot of children, so to feel being a mother for the second time. To give love to children as if they were my own." She started out by offering summer camp to school age children recognizing that children her daughter's age in her community were in need of care.

After receiving inquiries about care for younger children, Vera decided to establish home-based childcare. Vera differs from other participants in two ways, she is the only one that hires a part time assistant, and she provides childcare services to Russian speaking families only; thus, her program delivery is in Russian. She expressed,

... (I)n the summer there's no one, a lot of immigrants do not have grandmas, grandpas, so they're like us - alone, and like us they have to tread the waters alone in this Toronto. Because of that I offered just a summer daycare program, not like daycare it was more, all the kids were my daughter's age around six. When I started to advertise, moms started to call me and ask if I take kids from 18 months, and I said no I don't. And then they started to call, and call because people are interested (in childcare services). And then only about three months later I decided to make that step. 
Although Vera has been living in Canada for 17 years, she can still find a connection with recent Russian-speaking immigrants, who seek childcare arrangements similar to childcare provided back home.

\section{Being called unlicensed}

The issue with the language used to define unreguated home-based childcare providers (UHBC) came about unexpectedly in the participants' interviews. Because, the analysis of the language used in regards to UHBC was not intended, one of the first participants that was interviewed did not express her opinion on the matter. However, other participants expressed dissatisfaction to varying degrees with commonly used terms 'unlicensed' or 'unregulated' to refer to their and their peers' home-based childcares. Their dissatisfaction with the latter terms encompassed its negative connotations, being equated to illegal and operating without any rules, and public's misunderstanding of the licensing process of home-based childcares. In addition, some providers offered alternative terms they prefer to be called.

After speaking with UHBC providers, it was evident that the terms used to refer to their services mattered to them. They expressed that the terms 'unlicensed' and 'unregulated' encompasses certain connotations that reflect negatively on the UHBC providers. Some believe that the negative connotations of these terms have recently surfaced in the media coverage of the tragic events that took place in some UHBC. The emphasis on the negative aspects of UHBC, such as the lack of oversight or dubious quality in some UHBC, leads some participants to believe that the public has a one-sided perception, which is often negative, of the unregulated sector.

A lot of people, you know, are getting their first experience through these media reports of the unfortunate tragedies that have happened...And unfortunately, I've come into 
contact with a lot of people whose only knowledge is how the media portraying the unlicensed daycares. (Emily)

... (T)here's definitely a negative connotation that we are not licensed. It's like we, we as in home providers, you know don't have any rules, we don't follow any structure, you know, we're sitting your kids in front of the TV, that kind of thing. (Michelle)

As Michelle expressed above, the public is presented, in the opinions of the participants, with skewed images of UHBC as inadequate services for young children. Some participants expressed that the label 'unlicensed' is being equated to the label 'illegal'. For instance, Emily reasoned,

...(W)hen you see someone is driving without a license, someone is an unlicensed driver they should not be driving. So when they see unlicensed daycare, they automatically think that they shouldn't be running this daycare, they must be doing something wrong.

For that matter, she believes that the public often confuses the meaning of unlicensed and illegal home-based childcares, as one would think operating a home-based childcare without a license equates to carrying out an illegal activity. In addition, being without a license implies breaking rules set out by the licensing body. Thus, many participants expressed that the label 'unregulated' carries the connotation of operating without rules.

...Because to me saying unregulated (implies) that there's no rules, that's what that word means, unregulated industry there's no rules for it. And that's why people open up home childcare without even bothering to find out that they supposed to have a business license, if they advertise by a name, or that they supposed to have insurance, that they supposed to ensure that their business meets the fire code, that they supposed to ensure that their bness meets zoning...The language we use makes implications that there's no rules, when there are indeed rules. There're lots of rules" (Ava).

The complexities of licensing and regulating of home-based childcares, in some participants' opinions, have added to the confusion of what it means to be unlicensed/ unregulated. Most of the providers tried to correct this confusion by explaining that no homebased childcare in Ontario is technically licensed, only the private home child care agencies are 
licensed. The most that could be said about home-based childcares is that a third party regulates

them. Ava and Emily expressed the complexity of regulation thusly,

I don't like that language (unlicensed), and I don't like the language unregulated either. Because we're not unregulated, we still have regulations, and I'm not unlicensed, I do have a business lisence, so I don't like unlicensed either...Because if you call your daycare anything but your legal name, you have to have a business license in Ontario, that's the law. So I'm regulated there. I'm regulated by Public Health in what I'm allowed to do. I'm regulated by fire by-laws and what I'm allowed to do. So we're regulated, it's just we're not regulated by the Ministry of Education. So I hate that term to be honest.

And unfortunately a lot of people when they hear unlicensed daycares, they think illegal daycare and that's absolutely not the case. And they feel like, oh if I'm unlicensed, oh than you must not give me tax receits. No. Of course I give you tax receits, I'm very above board, I tell the government what I make, I'm a registered business. I do follow all the rules, I'm just not licensed. (Emily)

As most participants in this study expressed an aversion to the label 'unlicensed' or 'unregulated,' they felt that these labels unfairly depict their line of work, either as something accomplished illegally, or with a lack of quality. They expressed that these labels do not fully represent their UHBC. In light of this, most UHBC providers interviewed preferred their services to be referred to as independent, self-regulated, or private UHBC. Providers expressed that these terms are empowering, as they do not carry the weight of negative connotations like the term 'unlicensed'.

When people ask what I am I say I'm self regulated, that's what I am. Idependent is another word that I use. Independent, self-regulated those are words that are empowering and have dignity. (Ava)

...if I had a preference I would say private just because connotation people get, misunderstanding that they have when they see unlicensed. (Emily)

The terms that UHBC providers are rather to be referred to are not misleading, implying that the providers operate independently, outside of government or agency oversight.

\section{Choosing to remain unregulated}


To a great extent, all of the participants articulated a number of factors that influenced them to become or remain unregulated. These factors are the nature of licensing in Ontario, economic factors, flexibility, and control. A licensing process in Ontario encompasses private home child care agencies (hereafter the agency) that are licensed by the Ministry of Education to contract home-based childcare providers. Home-based childcares that are referred to as licensed are employees of the agency, and typically follow the policies set out by them in addition to following "Day Nurseries Act" (1990). Hannah expressed the frustration with this process,

Sure, I'd love to be licensed, that would be great, and I think I can easily pass. But to be licensed, I can't take my own independent business and get a license for myself, I have sign up with the agency. So I have gone through all the work myself setting up my business, getting my own pack and plays, highchairs, carseats, toys, my own clients, set this all up, I can run it all myself, but to get licensed I have to go through you and give you a minimum a $\$ 6$ per day per child. So, I checked (the agency) is non-for profit home childcare licensing agency... the amount that they take from your pay is $\$ 6$ per day per child. I did the math. I would lose $\$ 7,600$ and something dollars a year if I sign up with them.

Ava shares Hannah's sentiment,

Even if I went with an agency, I'm not licensed. The agency is licensed, I'm just contracted. If there's no agency children in the program they're not coming out and checking. They don't come out unless they've got actual kids in.

Ava and Michelle have used the term 'bureaucratic red tape' to describe relations with the agency. The red tape involved taking too long to assign children to a space and extensive set up procedures. Ava's account of child placement particularly stood out.

I called the agency, and I said I have a private client who's interested in my space, she's three weeks shy of her third birthday, but her mom needs her to start before the birthday, what do I do? She needs to find an alternative backup care for those three weeks because you can't take her. An I'm like, seriously, this is not in the best interest of this child, to go to another stranger for three weeks, that her mom doesn't necessarily like or want, how much more developed is this kid going to be in three weeks or how much more developed will my other children (be)? 
Ava relayed that in UHBC, she can accept a child based on development and personality, rather than adhere to a specific age bracket.

Some of the providers spoke about financial loss that occurs from being contracted through the agency. For instance, Emily shared that while she worked under the agency, she received approximately $50 \%$ of the parent fees charges by that agency. Ava expressed the consequences of a financial cut.

I'll be honest if I have to go back with an agency and live off of those wages I couldn't offer the food that I offer my clients, because somewhere I would have to cut services to maintain my income. So, that means I wouldn't able to offer gluten free menu, I would no longer be able to offer organic menu, they would find themselves eating what other people eat in agency. When I go to the Early Years Centre, I see my peers crack open a can of Purina dog chow, what I call it, can of beef stew, pop in the microwave and the kids share a $\$ 2$ can of crap. And they'll probably say, I hate feeding them this, but this is all I can afford. Because they're only getting paid $\$ 28$ a day from the agency. (Ava)

Michelle shared her experience of having to pay extra fees and around $20 \%$ of parent fees to the agency. Although, Vera and Patricia have not worked for the agency, they expressed a sense of unfairness of having to do all of the work while taking a pay cut. Vera claimed that because she provides unregulated care she is able to keep parent fees low.

You'd like to minimize payment for the parents, but what's the point for a mom to go back to work if she's going to make $\$ 1000$ or $\$ 1200$ and pay for childcare $\$ 1200$. There's no point, it would just be better for the mom to be with her own child and impart her love onto him, than give him to a strange lady. Thus, I want to minimize parents' fees, but due to agencies I would have to increase it.

Some participants, particularly those that have been contracted through the agency, expressed lack of control and freedom. For instance, Emily shared that her agency wanted every single account of conversations with parent.

They wanted like word for word conversation I had with the parents at the door. And if the parents had ever a concern or a question, I was to direct them to this agency and not answer it myself, which I had a really big issue about. 
The providers that have been under the agency have found the inability to interview and select their own clients as an issue. One provider believed she was "blacklisted" when she turned down parents sent to her by the agency by not having her vacant spaces filled. The ability to choose own clients is important to the providers, as they seek parents that have similar views on child rearing and educational philosophies. Remaining unregulated gives the providers control over selecting clients. Participants expressed that parent/caregiver relationship is better if both share similar philosophies.

...(A) parent that I interviewed yesterday has a girl who I think is 14 months and she's already toilet training her. And just the way that she spoke about, she always insist her child says thank you before she gives her something, it's not going to work for me. For me, I just like being polite to children and modeling, not saying, 'Hm, you have to say..." That's just not me. And the fact that she's already, you know, very pround that she's toileting this one one year old, it's like you're catching poops in the potty, that's what you're doing. So she's already got these very rigid philosophies that are not in-line with mine, it's not going to work. (Linda)

Working from home from the first point of contact it's just me and them, and so we can talk about values and we can talk about having a connection. It was one of the things that I learned in my first year too that I'm interviewing them just as much as they're interviewing me. And unlike my centre days where I just had to take any client who enrolled, I can choose and tailor people who share my values, so that we have less conflict, and we have less inconsistency in a program. (Ava)

Furthermore, unregulated care, according to participants, provides parents a choice to an approach to care and education that is different from centre-based care. Participants revealed many factors that differentiate their UHBC from centre-based care. The primary factor is the home-like atmosphere of the UHBC and the mother-like characteristics of the provider. Vera placed great emphasis on this aspect of UHBC.

It's more home like, it's more for the kids. More attention to individual child because in childcare centre there are big groups... Here, first of all more individual approach to children, here a small group size, this already says a lot, you can see more, pay attention to more. It's home like. Children feel like they are at home. (Vera) 
Many participants expressed the benefits of a home-like environment. According to the participants, the home-like atmosphere encompasses family-like relationships that are closely knit between the provider, children and parents.

It's a more tight contact. At a centre, there won't be such a tight contact between the carer and the parent. And it's a continuation of the family, that's why it's called family daycare, it's an extension of the family. (Vera)

The other lady that was part-time we are good friends now, she came to my house for my birthday, we had wine, we do meditation stuff together. I look at it, I am a mom too and somebody significant in their children's lives, I want them to be comfortable as long as we have this good, open relationship, they can come in when they want, the door is not locked, they can go to the fridge, it's open. In that area we're all taking care of the child together. (Linda)

... (W)e bonded and became close friends. We hang out whenever there's a family kind of thing, like there was jus it's called (Town) Food Truck Frenzy, it was a couple of weeks ago, so we all met there. There were times in the summer when we met, there was a free movie put on at the school and so I organize for all the daycare moms and their kids to come to it. (Patricia)

You know I'm not just one provider in the room. I have a relationship with these children. You care for them for three or four years, I'm almost going to cry, three of them are going, and it's really hard when they go. Yeah, I have a relationship with them, like they're kind of like your own kids...I think it's about having a close personal relationship with them, so you're giving them like a safe, great, homey place to be. (Hannah)

Some participants explained that due to them caring for children for a long time, typically at least for three years, these close relationships are possible. A close relationship with the parents allows providers to be in a consulting and a supportive role. For instance, Vera revealed that parents often ask her for advice on various matters, from how to put a child to sleep, to how to encourage a child to eat at family meals. Hannah expressed that supporting parents is one of the functions of UHBC provider, “... You're a sounding board for them, support for them.” She believes that being a mother herself enabled her to perform that function well. Hannah shared, ...(M)aybe an ECE in the centre doesn't have children of her own. Is the mom of Timmy going to go to her and say I just don't know what I'm going to do because I just can't get him to go to bed at night. She's no experience with that. (Hannah) 
Furthermore, the home-like environment provides flexibility within programing for the children and structure of the day. Michelle defined home childcare as laid back in comparison to centre-based care, where she believes the day is more structured. This laid-back attitude allows to change the course of the day to reflect children's needs. For instance, if a child feels ill, then the provider can engage with children in quite, reading activities while comforting the ill child; if, however, the children are bouncing of the walls, then the provider can take them outside unrestrained by scheduling.

They find that the home daycare is just more personable for the kids. Um, again less structure, you know, we all have those days where you're like I don't want to do those things, so it's kind of more laid back. (Michelle)

In addition to a laid-back environment the providers expressed flexibility within the program that is allowed by remaining unregulated. Providers who believed in the importance of being outdoors, considered that being an UHBC provides them with the flexibility to remain outdoors without being bounded by a regulated outdoor time. In addition, if they would like to take children on a field trip they would be able to do so spontaneously without having to jump through bureaucratic hoops.

I can do that (go on a field trip) because my parents sign a consent form saying, they give me permission to be spontaneous with the children as long as it's within this mile radius as long as it's within parameters we agree upon, and I can just go. You can't do that in a centre because "Day Nurseries Act" impedes that flexibility with rules that no longer make sense. (Ava)

The providers in this study revealed many factors that influence them to remain unregulated. The most pertinent factor is the regulatory system under which UHBC are governed. Under this system the providers reflected that they would lack control, structural flexibility, and freedom to provide the care and education that adheres to their values. Moreover, the providers would experience significant financial loss, which would result in a lower quality 
of care, or a business that would not be viable.

\section{Responding to the Bill 10}

Most of the participants were aware of the Bill 10, Childcare Modernization Act and expressed varying degrees of concern. Previously called Bill 143, the purpose of the Bill is to “enact the Child Care and Early Years Act, 2014, to repeal the "Day Nurseries Act", to amend the Early Childhood Educators Act, 2007, the Education Act and the Ministry of Training, Colleges and Universities Act and to make consequential and related amendments to other Acts" (Ontario. Regulatory Registry, 2014). The participants provided insight into proposed changes, particularly the "two under two" rule and increase of group size in RHBC, as well as shared their thoughts about government's approach to regulation of the UHBC.

The "two under two" rule stipulates that any UHBC provider will only be allowed to take on two children under the age of two. Currently this rule applies only to RHBC that work for agencies, but with Bill 10, it will also apply to the UHBCs. This rule poses a few problems for UHBC providers as described by participants. For example, currently Linda is taking in a cohort consisting of three children starting at age one and will care for them until they leave for kindergarten. If the "two under two" rule becomes active, then she would have to face a challenge of reducing to two children. Linda shared, "If they say I can only have two babies, that wouldn't be good for me, because you know, I love the three of the same age." Similarly, Michelle expressed concern of "cutting" children: "If this happens, I have to lose one child. And how do I go about cutting one child, how do I just randomly pick? A kid to cut. How would this affect them?" 
In addition to a dilemma of which child to let go, Hannah pointed to the economic consequence that the UHBC providers would have to bear due to decreased numbers of children a provider can care for.

So, you can have only two children under the age of two and most children in your care their oldest age is three and a half... you're not going to have five children in your care most of the time, because of that restriction...In my case, for example, have it already gone through, and I have my three older kids leaving at the end of this month, they're going to school. And in September, so I've got three kids who've just left and I need to fill those three spots the odds of me getting kids to fill those spots that are older than two are almost nill...So, then you're looking at having three or four kids in care in stead of five kids in care and for some people, they just won't able to make it work. Then they would have to close, and I talk to a lot of people, alot of people would have to close their daycare.

Economic loss is further exacerbated with the Bill's mandate for the UHBC providers to count their own children in the permitted numbers. Hannah made an interesting point. The UHBC providers that have their own young children in their care might no longer find their business viable, which might result in closing their home childcare and seeking a different source of income. The complication arises from having now to find childcare for their own children. ... (N)ow you've got all these providers who now need daycare for their kids, even if it's just before and after school care, whatever. I just think there will be a huge strain on the childcare system, particularly under twos. (Hannah)

The majority that I talked to, providers that I talked to say we have no problem having the Ministry in, no come look around if there's something I'm doing wrong let's figure it out. We just, we have to make a living too, and I think there's this connotation if the government passes it (Bill 10) we would have to cut our numbers we won't be able to make a living. And then what do we as parents, because there's not enough spaces for all the kids. (Michelle)

Both Ava and Hannah expressed the frustration with the government trying to encourage through the Bill 10 unregulated providers to sign up with the agencies. The allowance of an extra child, six instead of the current five, has these providers thinking that they would need to do extra work without appropriate compensation, due to agencies taking a portion of parent fees. 
For instance, if an unregulated provider begins to work for the agency, even though she can now care for six children, she will be technically paid for only five. Michelle and Patricia voiced this push to become regulated as a "cash grab on the part of the government" (Michelle) (albeit, the agencies are the ones that get the money). Ava phrased this sentiment succinctly,

Agencies are struggling because nobody wants to go with them. Parents can't afford to pay their fees and there's no subsidy... So they're trying to pressure us into going. That's not about quality, that's about greed, sorry...(I)t's not about quality at all, it's about increasing a profit margin, whether they're non profit or private, they need to be in the black. And so (the Agency) and some of those advocates pushing for this are private.

Despite participants' concern over Bill 10, many expressed openness towards regulation and provided ideas of what the government can do to appease both the public and the UHBC providers. Participants shared a need for the government to do something in order to prevent tragedy, as “children's safety shouldn't be leveraged because of the luck of the draw of who cares for them" (Ava). Some of them revealed that they would like to be directly licensed by the Ministry of Education and undergo a licensing process similar to childcare centres. In any case, participants claimed that the regulation has to be sound and coordinated with UHBC sector and the population it serves. Many providers are open to a registry database that anyone who operates a UHBC can use to register their childcare.

Everything can be done well. If the government met us halfway, and would write it all out in "Day Nurseries Act", nicely and adequetely, I don't think that there would be those that would not register. (Vera)

...(S)o that they actually know how many of us there are. Put us on a registry where we are agreeing that when we put our name on there, a statement of fact, or whatever, I agree to have no more than five children, I agree to follow basic, like, give us a health and safety checklist if they can't afford to send the people out, give us a checklist have us fill it out and make us have a witness, somebody else fill it out, yeah, the house meets these requirements. (Ava)

Ava and Vera have also discussed the number of children the government can consider allowing in UHBC. Ava expressed that this number cannot be arbitrary, as she thinks it is now, 
but reflect the average family composition. For instance, if an average household has two or three children, then the permitted number of children in UHBC needs should be seven or eight.

This line of logic comes from the current rule "five plus your own," which results in many

providers caring for seven to eight children legally. When these providers' children outgrow the

UHBC, the providers go back to caring for five children.

They need to start looking realistically at how children have been raised for centuries in a home in mix age groups, when once upon a time it was normal to have a family size of six to eight kids. Now, all of the sudden to say you can only have five kids and you have to count your own and is not indicated, like where do they come up with that? ...You have eight kids, one to two years appart so it's not uncommon to have eight children under the age of ten. The first chunk of them would have to be in school. Rather than saying, like my beef, they're your own, because it shouldn't matter, excuse my vulgarity if they popped out my vagina or yours, it doesn't matter on how much challenging they are to care for. So they would get more welcoming of providers if they said, we're going to tap at so I'm going to go with eight, five of them have to be or three of them have to be enrolled in school and the rest of them can be whatever age you're comfortable with, because if you got triplets you can't say you can only have two under two because somebody with triplets can never find care until their kids are over two. (Ava)

Vera also suggested that the government should allow more children in UHBC, although

her reasons were slightly different. She expressed that UHBC providers should be able to care

for more children if they have another person working with them (Vera is the only provider who

has an assistant in her UHBC).

But if you have an assistant that fully works with you, then limit the number to seven kids plus your own, two people with seven children can make it work. And plus it would benefit the parents because it wouldn't be an expensive childcare. Again, stipulate, like my situation, a person who has an (ECE) diploma, stipulate that this person is ready to work, for example, this person would have more of particular children...(I)f I worked with a lady that doesn't have a specialization and we can have seven children, and the government comes visit, we have an agreement that we can have seven kids, the government came, everything ok, just like plug the socket, or whatever, anyone would do that and continue with their work, if it's for enjoyment.

\section{Being a part of early childhood education and care sector}


All of the UHBC operators expressed that they have an important role in a broader early childhood education and care sector. The most commonly expressed role is that the UHBC provides parents with more childcare options. For example, Patricia and Emily talked about meeting childcare needs of families. They emphasized UHBC as a cheaper alternative to centrebased care. Emily stated,

I know a lot of parents who've come to me after trying licensed centres first... who have extremely long waitlists and they can't get it, or they are more pricier than I am and they can't afford it, or some childcare centres, and I don't know if it's everywhere or just in our area or what, but I know of a lot of parents who have felt out of loss that they have no choice but to go to unlicensed daycare because of a lot of childcare centres only, will take from 18 moths and up. So, I feel I like I'm a necessary service.

Vera expressed that because she provides home-based childcare in Russian, she meets the needs of immigrant parents, who may want to instill Russian language and culture onto their children. She believes that immigrant families seek care that reflects cultural values about upbringing. Moreover, Vera revealed that the presence of culture specific UHBC, ensures an easier transition to labour market for immigrant moms.

Similarly, Linda considers a home-based childcare a good transition for children from home to school, as well as a good transition for moms because, in Linda's opinion, they would be more

I think it can be a fantastic transition... It's a loving home-based, they can feel happy and comfortable with this situation, rather than shoving them into a daycare where there's lots of kids, lots of stuff and it's more institutional.

However, Linda made an interesting comparison between care by a mom for her own child and care by UHBC provider, pointing out that the latter is more of a teacher, whereas the former is just a mom.

Hannah, Ava and Michelle conveyed that the existence of UHBC provides parents with more options. For instance, Hannah shared that none of her parents considered centre-based care 
before coming to her, whereas, Michelle expressed the flexibility of UHBC provides families with a broader option.

(Home-based childcare) definitely has a role and a purpose. I think unfortunately it's under estimated. There's a lot of things unlicensed do that licensed won't even touch, special needs, in that sense number wise. Sick days, for example, PA days, sick day you know, your kids have the sniffles, a lot of especially the ones around here a lot of licensed, if you have a runny nose, you're home. (Michelle)

Flexibility in hours of operation plays a big part in Michelle's UHBC, who provides home-based childcare in a small suburban town. She expressed that being unregulated allows her to operate unusual hours, 5:30 AM to 5:30 PM. When she worked for the agency, her hours were set at 7:30 AM to 4:30 PM. However, this time frame was unrealistic because it did not reflect parents' working hours and lengthy commute to and from work.

I could be more flexible with my hours too, because before that they (the agency) kind of dictated how many hours I could have...I couldn't have a child any more than nine hours. Which is ok I guess, it's good if you live less than half hour from work. So it was really hard for the parents to get their eight hour work day plus to and from.

An array of options was illustrated by Patricia, who provides full-time and part-time childcare, providing before and after school care. Due to the close proximity of the school to her UHBC, she is able to walk school-aged children to and from school. Michelle, who also offers before and after school care, revealed that often UHBC providers are able to pick up children not only from school, but also from extracurricular activities. As such, parents might find UHBC an agreeable option, as they do not have to plan multiple child care arrangements, or involve extra people in taking care of pick-ups and drop-offs.

Overall, participants in this study illuminated UHBC sector by sharing their perspectives about the provision of unregulated childcare. They provided compelling arguments against becoming regulated under a licensed agency and the possible effects of Bill 10. These arguments 
ranged from financial strain of regulation to issues with flexibility. In addition, they provided interesting insights into the way their programs operate, such as flexible schedules and program delivery in a specific language. According to the participants, UHBC provides a greater option for parents, and in turn meets parents' unique needs for childcare. Some providers even revealed that because UHBC plays a prominent role in meeting parents' needs, an abrupt elimination of UHBCs would create a child care chaos in ECEC sector. 


\section{Chapter Six: Discussion}

This study explored the perceptions of unregulated home-based childcare (UHBC) operators about providing care for young children. In Ontario, only $20.8 \%$ of children have access to regulated care (Friendly, Halfon, Beach \& Forer, 2013), the other nearly $80 \%$ is in informal care that includes care by relatives, friends and unregulated home-based childcare. Previous studies that explored UHBC sector focused on global quality predictors (Doherty et al., 2006), provider qualifications (Hallam et al., 2013), and reasons for parental choice of UHBC (Huang, 2007; McKinley, 2010). However, researchers have not specifically studied the UHBC sector through an economic lens, particularly political economy of care, nor have sought to collect the perceptions of UHBC providers, which this study attempted to do.

Through semi-structured interviews, seven UHBC providers shared their perspectives about the factors that influenced them to begin to offer child care services, to remain unregulated, their opinions about Bill 10, and about their role in a broader early childhood education and care sector. Their perceptions were analyzed by employing political economy of care (PEC) theory as a lens through which the UHBC sector can be viewed. PEC scholars have extensively critiqued care economy, and thus provided conceptual tools for its analysis. However, as I dive into my own analysis using PEC theory, it is important to note my own struggle with reporting the findings through this lens.

On the one hand, I recognize these women's contribution to early childhood education and care (ECEC) sector. From my own perception of the interviews, UHBC providers devote their time, their space and endless effort in taking care of children in order to meet the needs of working parents. Considering my personal experience with UHBC, I have always respected and valued the work of UHBC providers. The participants' accounts of the work they are engaged in, 
its value and its challenges elevated my respect and understanding of unregulated child care sector to a new level.

On the other hand, I have to be aware of the socio-political context within which UHBCs operate. I have to acknowledge that the inexistence of a public child care policy leaves many parents seeking childcare in the market economy where at times the value of profit presides over the value of care. Parents must navigate through a complex system of childcare arrangements that includes informal care by a relative, UHBC, RHBC, for-profit or non-for-profit centre-based care, before and after school care, in addition to encountering a wide range of childcare fees and trying to decode requirements for childcare subsidy. Moreover, I must be conscious of the deaths of four children that happened last year in UHBC. As a parent, I wholeheartedly emphasize with their families.

Nonetheless, my aim as a researcher is to explore UHBC through a critical lens, yet not criticize it. Thus, the analysis of findings takes place within this struggle of respect and critique of UHBC. PEC theory allows for this critical exploration as it respects women's experiences providing an empathetic analysis of the issue. The discussion is organized by preliminary observations of how PEC interacts with participants' perceptions about their work. Although I discussed transnationalization as a feature of PEC theory, the findings did not demonstrate it. All of the UHBC providers were middle class, Canadian citizens, Caucasian, women entrepreneurs, characteristics that contradict the typical characteristics of a transnational care worker, who is a migrant from a developing country, of ethnic minority, and an employee of a much wealthier family. Thus, the discussion will not encompass transnationalization of care.

I will begin by discussing how participants' perceptions of 'home-like' and 'mother-like' care illustrates PEC's concept of social reproduction. Next, I will focus on participants' wish to 
remain unregulated, which is regarded by PEC scholars as an embodiment of a grey market economy. Following, the discussion will focus on solutions that address PEC as proposed by participants. I will end this chapter by proposing a reconfiguration of the current regulatory structure of UHBC.

\section{Unregulated home-based childcare and social reproduction}

A common theme runs through the accounts of providers' desire to operate a UHBC: the providers wanted to actualize maternal tendencies by nurturing children at home or emphasized 'home-like' atmosphere of the UHBC. Women's domain has for many years remained within a private sphere, the household, within which she carried out many responsibilities involving social reproduction activities that include but not limited to caring for children. The women in the study expressed that a home is the best site to care for children by juxtaposing it with the institutionalized centre-based care. Whereas children in a centre are herded through a rigidly structured environment, in a UHBC activities can be based on children's needs, "From nap time to lunch time, to snack, to weather...it can be entirely focused, like the mom will do, around the children" (Linda).

This finding reflects PEC scholars' description of social reproduction, as social reproductive labour is typically bound to households and performed by women. Some participants revealed the notion of home-based childcare to mean home-like atmosphere and family like relationships, particularly between a mother-like caregiver and the child she cares for. The linkage of concepts such as 'mother,' 'family,' 'like my children' with a notion of caregiver that provides care for economic sustenance is problematic. At a first glance, this link provides an image of a caregiver who is an affective carer. However, a deeper look reveals that the notion 
of a secondary or a substitute mother has deeper implications for women on the societal level (Folbre, 2006).

For one, the notion of 'home-like' carries a connotation that a household is the only site of care (social reproduction). Similarly, 'mother-like' care encompasses that care for children is solely a woman's responsibility. Because historically, social reproduction activities have been bound to households, childcare has remained a "core of domestic activities and as the area where gender divisions are starkest and hardest to change" (Razavi, 2007, p. 7). The linkage of the two concepts, 'home-like' and 'mother-like', within a UHBC reinforces unequal gender divisions pertaining to care labour, and justifies care labour as women's work.

On a broader societal level, these concepts perpetuate dominant ideologies and cultural tendencies about the role of women in regards to social reproduction. This results in the affirmation of the dominant social relations particularly pertaining to division of care responsibilities, instilling in the mindsets of individuals assumptions about care responsibilities (Bedford \& Rai, 2009). In as much as, predominantly the views of society are that women's capabilities to care are subsumed in the fact that she is a mother, or even a woman. Hypothetically speaking, if a stay at home dad became a UHBC operator, would he be considered qualified to provide good care?

Furthermore, the notion of natural progression from being a mom on maternity leave, or a stay at home mom to becoming a UHBC provider revealed by the participants illustrates another implication for women in society. As women began to gain an easier access into the labour market, and took on the responsibility for the economic sustainability of their families, the work of caring for children shifted from being in the domain of the household to the domains of market economy and public services. For some participants in this study this shift was not a 
natural choice. For instance, Michelle and Emily are parents to children with disabilities; as parents, they voiced that their children's needs may not have been met at a centre-based childcare. For others, it was a matter of having to personally raise their children. For them caring for their own children at home was a natural progression. For them it made sense to continue to be a stay at home mom with an additional benefit of providing financially for their families. A quote from Michelle represents this sentiment nicely,

Majority of us are moms that came into home daycare going, ok there's a need for this obviously, financially, as well as just for our own kids, our own kid's needs, or special needs, and just as it can't be met at the licensed, and there's no spots. (Michelle)

The notion of natural progression from a mother to a caregiver further exacerbates the gendered aspect of the social reproductive labour. It assumes that caring for children is innate to women. The assumption that women are genetically inclined to take care of children has a number of implications for women and society. First, as the responsibility for care is placed with women, women who chose not to engage in child care might face harsher criticism by resisting gender norms instilled through the dominant discourses on care, and public policies that reinforce traditional models of social reproduction.

Second, this assumption potentially abdicates mothers' male counterparts from caring responsibilities. Although men have been increasingly taking on social reproductive labour, the bulk of it, including caring for children, still rests with women. Unfortunately, women themselves reproduce the idea that only mom can care, as was observed with participants' use of the 'mom-like' notion. In a way, this prohibits men from entering women's domain and taking on care responsibilities. Furthermore, this perpetuates gender divisions within social reproductive work, because unlike a woman, a man's ability to care is not contingent on his biology but rather on a skill to care. 
This brings me to a third point, being a mother is in itself a qualification to care for others' children. Consequently, an additional knowledge about early childhood education and care may not be considered as useful. This results in perpetuating the assumption that the work of caring for children is an unskilled work (McGrath \& DeFillipis, 2009). This in itself can have implications of driving the value of care down ideologically as well as economically. Lastly, the notion of natural progression reproduces the gender norms in regards to social reproductive labour. If the women are naturally inclined to care for children, then this type of care is 'natural' (best) and should be reinforced through social policies that allow women to stay home, rather than encourage to participate in a labour market. The notion of natural progression from motherhood to caregiver is highly problematic as it potentially worsens women's position in a society by increasing barriers into the labour market participation.

Not only the assumption of social reproductive activities encompasses and perpetuates a greater gender divide, but also further devalues women's care work in the market economy (McGrath \& DeFilippis, 2009). Devaluation of women's social reproductive work through the market comes out of women performing the same line of work in the household on unpaid basis. Following that, if a woman can do care work for free, and has done so for centuries, then her demand to be highly remunerated for the same work is unjustified. This devaluation of care work “supports the ideological distinction between the 'women's work' performed by care workers and the 'real jobs' held by, for example, their employers" (McGrath \& DeFilippis, 2009, p. 69).

This is evident in Michelle's account of parents not being very appreciative, or valuing the work she does, "You're just a stay at home mom, you don't really do anything"; although, she attributes these comments not intrinsically coming from the parents, but them reflecting the media and society's construction of UHBC providers. Yet, parents might have the assumption 
that they in fact hold real jobs, they go out to participate in the labour market, whereas the UHBC provider stays at home, and acts as a substitute mother.

As a result, the women in the study, who operate UHBCs, are engaged in social reproduction activities by reproducing human capital and reproducing dominant ideologies and cultural tendencies. The former is accomplished through the physical labour of caring for children, and the latter through the reinforcement of 'home-like' and 'mother-like' concepts. Although care for children in a centre based environment is also an act of social reproduction, notions of 'home-like' and 'mother-like' are absent. This divorce of the caregiver concept from the mother concept in an institutional setting may explain a higher emphasis on skills rather than innate capabilities.

It is important to acknowledge that the participants in this study, even though they might be engendering social reproduction, are in the UHBC sector because of socio-political push factors (Hankivsky, 2011). For instance, in addition to being a mother some women expressed economic sustainability as an influence to operate UHBC, or desirability of better work/life balance. Given their life circumstances, they are supporting financial sustainability of their families, and simultaneously support other families within their communities.

\section{Unregulated home-based childcare: A grey market}

Economic pressures preside over households, as it is much harder to financially sustain a family on a single earner income and having both parents earners ensures economic security (Friendly \& Prentice, 2009; McKinley, 2010). Seemingly, the solution to this dilemma of caring for one's children and contributing financially to the household is to begin to provide childcare for other's children for economic gains. For some participants in this study, operating UHBC is a viable choice that permits them to care for their children and contribute financially to the 
household. As they become players in the market economy, the women are transcending the boundaries of private/public because they continue the social reproductive work in their households but are also participating in a labour market.

PEC scholars would situate UHBC within a grey market economy because the UHBC sector captured by this study is void of the typical childcare regulations that the centre-based childcares abide by. The providers in this study consider themselves entrepreneurs and follow principles of the market in as much as they try to manage the cost of provision of care services. The range of parent fees that participating providers charge illustrates the aspect of market economy when the fees vary according to geographical location of the provider. The UHBC providers are able to set parameters around the care they provide, negotiating an optimal care relationship for themselves. For instance, participants noted that they interview parents as much as the parents interview them, ensuring that their ideologies are aligned.

Williams (2011) terms the provision of care through the market, a "marketized childcare economy" (p. 23). Within a marketized childcare economy, parents are conceptualized as individual consumers trying to find care for the right value for money. The UHBC sector feeds into this by often providing cheaper and accommodating care arrangements. For instance, participants expressed the benefits of UHBC such as flexible hours, including part-time, and before and after school care, and flexible programming as features that draw parents to unregulated sector. Because UHBC operates within a marketized childcare economy, varied elements of care services offered by providers of UHBC can be understood as marketable features. As such, a marketable feature, such as flexible hours or alternative curriculum approach, acts to attract consumers who are weighing care services options in trying to choose the right UHBC provider within a market. 
However, the care economy that these providers are in, although follows the rules of the market, is complicated by close relationships and care obligations (Held, 2006). Many participants expressed the family and friend like relationships with parents and children. Here the boundary between the business and the consumer is not as clear-cut as it would be in the typical market economy. Some participants shared that they attend each other's celebrations, and their children play outside of the hours of home-based childcare. These kinds of relationships between the care provider and care purchaser contradict the notion of dependency explored by PEC scholars in relation to care workers (Williams, 2010; Yeates, 2005). The PEC scholars delineate care workers' dependency on their employer because typically the care worker is conceptualized as a minority of a low socio-economic status, and in addition has limited rights because she works within a grey market economy. However, the care workers in this study operate within the grey market to their own perceived benefit; and rather being solely dependent on parents who buy their services, they find themselves being interdependent, as the parents depend on their services, as much as they depend on parents for income.

Nevertheless, because the operations within grey markets are considered informal, there are fewer regulations overseeing their processes. On the one hand, due to the absence of regulation UHBC providers are in full control of their businesses. As many providers have expressed, they have the ability to operate their UHBC based on the children's, parents' and their needs. The accommodation of these needs can range from operating during non-standard hours to flexibility in the programming, to being able to take spontaneous field trips. Many providers particularly that have worked under a licensed private-home childcare agency (the agency) expressed the rigidity of regulation imposed by those agencies, and financial loss that accrues from being regulated. For instance, one provider calculated that working under a non-for-profit 
agency she would lose approximately $\$ 7600$ annually. For-profit agencies can charge as much as $50 \%$ of provider's earnings, according to another participant. Hence, for these providers it makes an economic sense to remain unregulated. Another provider expressed that the regulatory policies she endured while working at a centre-based childcare influenced her to become UHBC operator where she can be in control of programming for children in her care.

On the other hand, being a part of a grey market comes with its challenges. Some providers expressed the precariousness of their situation in terms of their income being contingent on the number of children in their care. If families decide to withdraw from their UHBC, then providers are left to cover the cost of their programs by redistributing fees from the remaining families. For instance, if a provider received income from caring for five children, then if she 'loses' even one child her income becomes reduced; however, her costs of providing care may not decrease, as she still has to cover her operational costs (housing, meals,). For that matter, many participants expressed concerns over Bill 10, as it purports to reduce the number of children they are allowed to care for.

The presence or absence of particular social policies plays a role in reinforcing a grey market economy within which UHBCs operate. Since governments have been adhering to neoliberal ideologies, the public services have been downsized in the name of fiscal responsibility. The markets then have picked up the slack, as the need for services has not subsided. For governments, the existence of grey markets, such as UHBC sector, is optimal because they cater to population's needs at minimal expense for governments (McGrath and DeFilippis, 2009). Furthermore, neoliberal social policies reinforce gendered provision of social reproductive labour (Yeates, 2005). For example, Canada's Universal Child Care Benefit (UCCB) is a taxable cash transfer issued monthly to parents to supplement childcare costs. 
However, the $\$ 100$ a month can afford about one and a half days in centre-based childcare, and two days in home-based childcare. Moreover, the Federal government cannot account for this cash transfer being spent on childcare as it has not analyzed how the UCCB funds are used and by whom (Friendly, 2013). Nonetheless, the underlying assumption of this policy is that social reproductive labour is a private matter, and should be undertaken by parents, not the state.

\section{UHBC providers addressing Political Economy of Care}

Although the UHBC providers in this study perpetuate political economy of care, they also seek solutions to address it. They address care economy in three ways. Firstly, they are resisting grey markets by advocating for a sound regulation of UHBC sector. All of the UHBC providers expressed that they would like to be regulated. They want to come out of the ‘invisible’ economy and be recognized for their work (Razavi, 2007). However, they need a sound regulatory system that would provide accountability to parents, and could raise the value of UHBC providers' work. The Bill 10, Child Care Modernization Act that is currently being

reviewed in legislature, although purports to increase oversight of the UHBC sector, would fail at bringing UHBC out of a grey market economy. Strict regulations have been shown to affect childcare providers negatively by reducing childcare services and increasing parental fees (Blau, 2003). These effects of regulation were expressed by the participants in this study, particularly regulation of children's ages in UHBC — the two under two rule. Providers perceive the consequences of Bill 10 to be a loss of childcare spaces, resulting in many providers' inability to financially sustain their UHBC. Furthermore, this type of regulation risks reducing participation of mothers with young children in the labour market (Blau, 2003). Coincidently, the lack of spaces and elevated costs of childcare could encourage some women to extend their maternity leaves on an unpaid basis. 
Secondly, the UHBC providers in this study address PEC by being active actors in the market economy. PEC scholars have predominantly focused on domestic care workers that are directly employed by the care services consumer. For instance, a nanny would be employed by one family to provide care to related children. A nanny's work satisfaction, and to an extent financial well-being is contingent on a relationship with her employer. Thus, a nanny often endures power imbalances that are interlaced with the affective relationships with the children she cares for, and the economic dependence on her employer (Williams, 2010).

The women working in the UHBC sector are self-employed, and to an extent economically independent (Cox, 2005). Because a provider and a parent make a business transaction, both can negotiate the terms of the services provided. Many participants illustrated the control they have over their businesses by having an ability to choose the parents that buy their services as much as parents choose them. This aspect is important to UHBC providers in this study because they perceive a relationship with like-minded parents to contribute to quality of care. Furthermore, most of the UHBC providers have clearly articulated policies in a form of parent handbook. Thus, when the parents buy in into their services, they know what to expect, and can make a choice whether or not these policies suit their needs.

Thirdly, the UHBC providers are addressing the assumption that UHBC is an inadequate care arrangement for young children. The participants in this study have perceived their UHBC to be of higher quality than centre-based care. Through their accounts, they demonstrated versatility of their programs that follow children's needs rather than set schedules. To an extent, they are resisting the institutionalization of care, which according to the providers is associated with rigidity and impersonable relationships, by embodying the ethics of care. Considering that both the provider and the family engage in selecting each other, they share a mutual 
understanding, which is important for developing trust (Held, 2006). Because the UHBC providers care for a few children over a long period of time, they develop close knit relationships, causing them to recognize and value the complex interwoven connections between themselves, children and parents. As a result of embodying the ethics of care, UHBC providers elevate the quality of their care work.

\section{Home-based childcare within ECEC system}

Although childcare advocates have long advocated for a high quality publically funded early childhood education and care (ECEC) system that would serve all Canadians (Friendly \& Prentice, 2009), home-based childcare has been largely absent from this ideal. The tensions between public and private provision of care are well documented, where research favours public, or non-for-profit provision of childcare. Because UHBC is operated as a business in a grey market economy, it is left on the periphery of the auspice conversation. However, UHBC occupies a large portion of the ECEC sector as nearly $80 \%$ of children attend unregulated care (Ferns \& Friendly, 2014). Thus, I cannot help but wonder is there a place for home-based childcare whether regulated or not in ECEC sector, and under what kind of regulatory conditions?

As a proponent of a universal childcare system, I recognize its importance. Perhaps if families had an access to a publically funded childcare system that can accommodate their unique needs, then many families would not seek services of home-based childcare providers. However, if there are families that would still prefer a home-based childcare, then they need to have access to providers that are regulated and thus accountable to the public for provision of quality care. This will not only elevate the quality of home-based childcare, but also bring them out of a grey market economy and enable them to have a voice within ECEC sector. It is beyond 
the scope of this paper to describe a possibility of home-based childcare within a universal ECEC system. However, what follows is an exploration of possible conditions under which home-based childcare can function and provide quality care to children in the interim.

Currently, regulated UHBC is contracted through a licensed agency. This process creates a challenging financial situation for a provider, as the agency charges a range of fees. According to participants in this study, many providers choose to operate an UHBC because of these structural challenges. However, an UHBC sector does not have avenues for accountability to the families that purchase their services. The only regulatory body that can somewhat keep the UHBC sector accountable to the public is the Ministry of Education. However, the Ministry becomes involved only when it receives a complaint from the public, and its only reinforcement of quality is through enforcement of legal numbers of children in the care of providers.

The Ontario government needs to adapt a solid regulatory strategy that would benefit both the public and the UHBC providers. Firstly, the Ministry of Education has to create a website with a database for registry for all UHBC. Such a website can serve as a resource for providers where they can have access to health and safety checklists, safe food handling practices, quality checklists in addition to education and care resources. This avenue for registration will not ensure that all UHBC providers will register their childcare; however, it would be in the provider's best interest to register because parents that seek quality care for their children will most likely try to find a provider through a government registry.

Secondly, the Ministry of Education needs to take the reins on agencies. They charge, at times, unreasonable fees that deter UHBC providers from being overseen by them. Perhaps, to encourage UHBC providers to be overseen by the agency, the government needs to cap agencies' fees, akin to what the centre-based childcares pay the Ministry for their license. Ideally, however, 
UHBC should be overseen directly by Ministry personnel to avoid policy interpretations by an intermediary. At the very least, contract agencies for the purpose of conducting inspections only.

Lastly, I propose that UHBC providers be connected to public childcare centres within their communities. A centre supervisor can liaison with UHBC provider, offering support and access to resources. This has to be a reciprocal relationship, not top down, because the UHBC provider also has something to offer to centre staff. UHBC providers can attend supervisors meetings held by the Ministry of Education. In this way, providers will be kept updated on the matters pertinent to ECEC sector. Although these measures might seem overly optimistic, they could provide avenues for accountability and transparency of the UHBC sector.

In this chapter, unregulated home-based childcare (UHBC) providers' perceptions have been analyzed through the critical lens of the political economy of care (PEC) theory. PEC theory has illuminated UHBC providers as perpetuating gendered roles in the care economy through social reproductive labour. It has problematized the UHBC providers' presence within a grey market economy. However, the analysis also revealed contradictions to PEC theory, such as the absence of transnationalization of care, providers' active engagement within a grey market economy, and providers' desire to come out of a grey market economy by being open to regulation. In this chapter, a possible interim regulatory structure was also presented.

\section{Conclusion}

In this qualitative research study, seven unregulated home-based childcare (UHBC) providers were interviewed in order to capture a snapshot of the UHBC sector. It was not my intention to criticize or evaluate UHBC providers, but to understand care work conducted in an unregulated sector. I used political economy of care (PEC) theory in order to analyze providers' perceptions about their work because in addition to problematizing care regimes, PEC theory 
values the voices of women and provides solutions to address care issues at a global and state levels.

Analysis of participants' interviews revealed certain pulls within the provision of unregulated care. On the one hand, UHBC providers engage in social reproductive work that perpetuates gendered assumptions of women's domain, such as reinforcing women's role in caring for children. In addition, by remaining unregulated, providers reinforce a grey market economy as a site for provision of care services. Both of these aspects of UHBC, social reproduction and a grey market economy have a potential to further devalue care work. On the other hand, PEC lens revealed that UHBC providers in this study are actively addressing the issues exposed by PEC scholars by being open to regulation, as long as it benefits them as well as the families that use UHBC, by believing in providing quality care that meets a range of the families' needs, and by being entrepreneurs rather than employees of care work.

These findings have implications for the current system of home-based childcare regulation and the proposed amendments to it through Bill 10. The proposed regulation is not trying to bring UHBC sector out of a grey market economy, nor encourage quality, as the enforcement of the law occurs after its violations. I proposed an interim regulatory system that enables accountability, transparency and sustainability of UHBC through UHBC registry, direct licensing by the Ministry of Education, and community networking whereby UHBC provider has a professional relationship with centre-based early childhood educators. A sound regulatory system would bring the UHBC sector out of the grey market, and enable home-based childcare providers to have a voice in early childhood education and care sector.

Moreover, the unregulated childcare sector is under represented in the literature on homebased childcare, especially in a Canadian context. Researchers need to investigate UHBC in 
respect to different cultures, geographical areas (rural versus urban), and encompass a large sample of UHBC providers in order to establish patterns of characteristics providers embody. Additionally, researchers need to examine UHBC provider's perceptions about a regulatory system that would work for them, and examine their perceptions about what a universal publically funded system means to them. Addressing these questions means to acknowledge the fact that most of Canadian children are cared for within UHBC. In my opinion, a dismissal of UHBC providers' voices does disservice to the children and families they serve. 
Appendix A. Interview Protocol

Interview protocol

Time of the interview:

Date:

Place:

Participant:

Demographic Information:

1. Age: $18-24 \quad 25-34 \quad 35-44$

2. Gender:

3. Ethnicity:

4. Marital Status:

5. Years living in Canada (if applicable):

6. What would you say your job title is?

7. Education and/or Qualifications:

8. Years in business:

9. Income: The average hourly wage of a childcare staff in Ontario is $\$ 17.29 /$ hour (YBWSC, 2013) . Would you place yourself:

(way below average) (below average) (average) (above average) (way above average)

10. Do you have any of your own children in your home childcare? How many?

11. What are the ages of children you accept?

Questions:

1. What influenced or inspired you to begin providing care?

a. When you first opened, did you experience any challenged? Would you mind sharing what those challenges were?

b. Did you have any challenges getting children?

c. How do parents usually find you if they want to use your services?

2. Tell me about yourself as a childcare provider.

a. What are your thoughts about caring for children?

b. What are your thoughts about education and young children?

c. Do you follow any care/education philosophy (personal or "professional") or program? 
3. Tell me about your program?

a. What are the ages of children?

b. Do you have any children with special needs?

c. Hours of operation?

d. Cost of childcare services? You can give me an approximation or a range.

4. What is a typical day like for you?

a. Schedule, daily/ monthly program, routines, interaction with parents?

5. Does somebody help you during the day? If yes, how many and for what proportion of the day?

a. What do they help you with?

6. Can you describe your relationship with parents?

a. Can you explain what is a (good/bad/so-so) relationship? (What do you mean by that?)

b. Can you provide examples?

7. Do you have written policies/ rules about the way your home childcare operated? If yes, How do you communicate these policies to parents?

a. Can you provide some examples of your policies/rules?

8. Do you connect with other childcare providers? How?

9. Do you use community services, like libraries, drop-in centres, play groups?

10. Is there a particular constituency of parents that appeal to you in regards to language and/or culture? Can you give an example, please?

11. How do you view your role in caring for children?

12. How would you distinguish your home childcare from centre-based childcare?

a. Do you think the services you provide are different? If so, how are they different?

13. What do you think your role is in the broader childcare sector, in so far as being an unlicensed, home-based provider among the licensed home-based childcares and centre-based childcares? 
14. The Ontario government is in the process of passing a law that will affect the number of children allowed in unlicensed home-based childcare, and increase fines for violations of rules. How do you think that law will affect your unlicensed home-based childcare? How will the law affect you role as childcare provider?

15. Would you mind sharing your goals and aspirations for the future in terms of your home childcare?

16. Is there anything else you would like to add? 


\section{References}

Archer, K. \& Berdahl, L. (2011) Explorations: Conducting empirical research in Canadian political science. ( $2^{\text {nd }}$ Editions). Don Mills, ON: Oxford University Press.

Armenia, A. B. (2009). More than motherhood: Reasons for becoming a family day care provider. Journal of Family Issues, 30 (4), 554-574.

Bakker, I., \& Silvey, R. (Eds.). (2008). Beyond States and Markets: The Challenges of Social Reproduction. England: Routledge.

Ballingall, A., \& Oved, M. C.(2014, February 26). Baby found dead in unlicensed daycare. The Toronto Star. Retrieved from http://www.thestar.com

Barber, K. (Ed.). (2004). Canadian Oxford Dictionary ( $2^{\text {nd }}$ ed.). Toronto, Canada: Oxford University Press.

Bedford, K., \& Rai, S. M. (2010). Feminists theorize international political economy. Signs, $36(1), 1-18$.

Bezanson, K., \& Carter, E. (2006). Public Policy and Social Reproduction: Gendering Social Capital. Ottawa: Status of Women Canada.

Bill 10: Child Care Modernization Act. (2014). 1st Reading Jul. 10, 2014, $41^{\text {st }}$ Parliament, $1^{\text {st }}$ session. Retrieved from The Legislative Assembly of Ontario website: http://www.ontla.on.ca/web/bills/bills_detail.do?locale=en \&BillID=3002\&detailPage=bil $\underline{\text { 1s_detail_the bill }}$

Blau D. M. (2007). Unintended consequences of child care regulations. Labor Economics, 14, 513-538.

Blau, D. (2003). Do child care regulations affect the child care and labor markets? Journal of Policy Analysis and Management, 22(3), 443-465. 
Butler, J. A. \& Modaff, D. P. (2008). When work is home: Agency, structure, and contradictions. Management Communication Quarterly, 22 (2), 232-257.

Cameron, B. (2006). Whose social reproduction? Transnational motherhood and challenges to feminist political economy. In Bezanson, K. \& Luxton, M. (Eds.). Social Reproduction : Feminist Political Economy Challenges Neo-liberalism. Montreal : McGill-Queen's University Press.

Check, J., \& Schutt, R. (2012) Research methods in education. Thousand Oaks: Sage.

Connell, R. (2010). Understanding neoliberalism. In Braedley, S. and Luxton, M. (Eds), Neoliberalism and Everyday Life. Canada: McGill-Queen’s University Press, pp. 22-36.

Cox, R. (2005). Making family child care work: Strategies for improving the working conditions of family childcare providers. Ottawa: Status of Women Canada.

Creswell, J. (1998). Qualitative inquiry and research design: Choosing among five traditions ( $2^{\text {nd }}$ ed.). Thousand Oaks, California: Sage Publications Inc.

Creswell, J. (2014) Research Design: Qualitative, quantitative, and mixed method approaches. Thousand Oaks, California: Sage Publications Inc.

Davies, B., and Bansel, P. (2007). Neoliberalism and education. International Journal of Qualitative Studies in Education, 20(3), pp. 247-259.

Day Nurseries Act, Revised Statutes of Ontario (1990, c. D-2). Retrieved from Service Ontario eLaws website: http://www.elaws.gov.on.ca/html/statutes/english/elaws_statutes_90d02_e.htm

Doherty, G., Forer, B., Lero, D. S., Goelman, H., LaGrange, A. (2006). Predictors of quality in family child. Early Childhood Research Quarterly, 21, 296-312. 
Dowling, M. (2008). Reflexivity. In Given, L. M. (Ed.), The SAGE Encyclopedia of Qualitative Research Methods. (pp. 863-864). Thousand Oaks, CA: SAGE Publications, Inc.

Ferns, C. \& Friendly, M. (2014). The State of Early Childhood Education and Care in Canada 2012. Toronto: Childcare Resource and Research Unit.

Folbre, N. (2006). Rethinking the child care sector. Journal of the Community Development Society, 37 (2), 38-52.

Freeman, R. (2011). Home, school partnerships in family child care: Providers' relationships within their communities. Early Child Development and Care, 181 (6), 827-845.

Friendly, M. \& Prentice, S. (2009). About Canada: Childcare. Halifax: Fernwood Publishing. Friendly, M. (2013). The $\$ 17.5$ billion question: Has the Universal Child Care Benefit given families "choice in child care"? Briefing Notes. Toronto: Childcare Resource and Research Unit.

Friendly, M., Halfon, S., Beach, J. \& Forer, B. (2013). Early childhood education and care in Canada 2012. Toronto: Childcare Resource and Research Unit.

Gabriel, (2011). Migration and globalized care work: The case of internationally educated nurses in Canada. In Mahon, R. \& Robinson, F. (Eds.), Feminist Ethics and Social Policy: Towards a New Global Political Economy of Care (pp. 39-59). Vancouver: University of British Columbia Press.

Galloway, G. (2011, February 4). It's about choice, Diane Finley says, not disdain for daycare. The Globe and Mail. Retrieved from http://www.theglobeandmail.com/news/politics/ottawa-notebook/its-about-choice-dianefinley-says-not-disdain-for-daycare/article611465/ 
Hallam, R. A., Bargreen, K. N., and Ridgley, R. (2013). Quality in family child care settings: The relationship between provider educational experiences and global quality scores in a statewide quality rating and improvement system. Journal of Research in Childhood Education, 27, 393-406.

Hankivsky, O. (2011). The dark side of care: The push factors of human trafficking. In Mahon, R. \& Robinson, F. (Eds.), Feminist Ethics and Social Policy: Towards a New Global Political Economy of Care (pp. 145-161). Vancouver: University of British Columbia Press.

Held, V. (2006). The Ethics of Care: Personal, Political, and Global. Oxford University Press. Huang, G. H.-C. (2007). What I'm looking for: Family day care from the parent's perspective. Education, 128(1), 114-124.

Hughes, R. (2008). Telephone Interview. In Given, L. M. (Ed.), The SAGE Encyclopedia of Qualitative Research Methods. (pp. 863-864). Thousand Oaks, CA: SAGE Publications, Inc.

Hughes-Belding, K., Hegland, S., Stein, A., Sideris, J., Bryant, D. (2012). Predictors of global quality in family child care homes: Structural and belief characteristics. Early Education and Development, 23, 697-712.

Lanigan, J. D. (2011). Family child care providers' perspectives regarding effective professional development and their role in the child care system: A qualitative study. Early Childhood Education Journal, 38, 399-409.

Luxton, M. (2006). Feminist political economy in Canada and the politics of social reproduction. In Bezanson, K. \& Luxton, M. (Eds.), Social Reproduction : Feminist Political Economy Challenges Neo-liberalism. Montreal : McGill-Queen's University Press. 
Macdonald, L. (2013). Can ECE professionals be advocates? Perspectives from the child care advocacy movement in Manitoba and Ontario.(Major research paper). Toronto: Ryerson University.

Mahon, R. \& Robinson, F. (Eds.). (2011). Feminist Ethics and Social Policy: Towards a New Global Political Economy of Care. Vancouver: University of British Columbia Press.

Maxwell, J. (2009) Designing a qualitative study. In D. J. Rogg \& L. Bickman (Eds.) The Sage handbook of applied social research. Thousand Oaks: Sage.

McGrath, S. \& DeFilippis, J. (2009). Social reproduction as unregulated work. Work, Employment and Society, 23(1), 66-83.

McKinley, R. (2010). Child care by choice or by default? Examining the experiences of unregulated home-based child care for women in paid work and training. (Unpublished Masters of Arts thesis). St Catherine's, Ontario: Brock University.

Miller, P., Votruba-Drzal, E., \& Levine Coley, R. (2013). Predictors of early care and education type among preschool-aged children in immigrant families: The role of region of origin and characteristics of the immigrant experience. Children and Youth Services Review, 35, $1342-1355$.

Ministry of Children and Youth Services. (2010). Reporting Child Abuse and Neglect: It's your Duty Your Responsibility under the Child and Family Services Act. Ontario: Queen's Printer for Ontario.

Ontario. Ministry of Education. (2013a). Licensing; Standards, legislation, and inspection. Retrieved from http://www.edu.gov.on.ca/childcare/licensingstandards.html\#display Ontario. Ministry of Education. (2013b). Child Care Choices. Retrieved from http://www.edu.gov.on.ca/childcare/choices.html 
Ontario. Ministry of Education. (2014). Unlicensed Child Care. Retrieved from http://www.edu.gov.on.ca/childcare/unlicensed.html

Ontario. Regulatory Registry. (2014). Proposal to Amend Regulation 262 under the Day Nurseries Act - Child Care Modernization Document. Retrieved from: http://www.ontariocanada.com/registry/view.do?postingId=14762

Raikes, A., Raikes, H. H., Wilcox, B. (2005). Regulation, subsidy receipt and provider characteristics: What predicts quality in child care homes? Early Childhood Research Quarterly, 20,164-184.

Razavi, S. (2007). The political and social economy of care in a development context. Gender and Development Programme Paper, (3). United Nations Research Institute for Social Development.

Rusby, J. C., Jones, L. B., Crowley, R., Smolkowski, K., Arthun, C. (2013). Predictors of homebased child care providers' participation in professional development workshops and coaching. Child Youth Care Forum, 42, 439-455.

Tronto, J. (2011). A feminist democratic ethics of care and global care workers: Citizenship and responsibility. In Mahon, R. \& Robinson, F. (Eds.), Feminist Ethics and Social Policy: Towards a New Global Political Economy of Care (pp. 162-177). Vancouver: University of British Columbia Press.

Van den Hoonaard, D. K. (2012). Qualitative research on action: A Canadian primer. Don Mills, Ontario: OUP Canada.

Williams, F. (2010). Migration and care: Themes, concepts and challenges. Social Policy \& Society, 9(3), 385-396. 
Williams, F. (2011). Towards a Transnational analysis of the political economy of care. In Mahon, R. \& Robinson, F. (Eds.), Feminist Ethics and Social Policy: Towards a New Global Political Economy of Care. (pp. 21-38). Vancouver: University of British Columbia Press.

Yeates, N. (2005). A global political economy of care. Social Policy \& Society, 4(2), 227-234. 